ARTICLE

\title{
Tuning the activities of cuprous oxide nanostructures via the oxide-metal interaction
}

\author{
Wugen Huang ${ }^{1,2,7}$, Qingfei Liu1,2,6,7, Zhiwen Zhou'1,2, Yangsheng Li ${ }^{1,2}$, Yunjian Ling ${ }^{1,2}$, Yong Wang ${ }^{3}$,

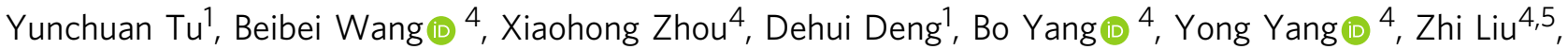 \\ Xinhe Bao ${ }^{1} \&$ Fan Yang (1,4凶
}

Despite tremendous importance in catalysis, the design of oxide-metal interface has been hampered by the limited understanding of the nature of interfacial sites and the oxide-metal interaction (OMI). Through construction of well-defined $\mathrm{Cu}_{2} \mathrm{O} / \mathrm{Pt}, \mathrm{Cu}_{2} \mathrm{O} / \mathrm{Ag}$ and $\mathrm{Cu}_{2} \mathrm{O} / \mathrm{Au}$ interfaces, we find that $\mathrm{Cu}_{2} \mathrm{O}$ nanostructures (NSs) on Pt exhibit much lower thermal stability than on $\mathrm{Ag}$ and $\mathrm{Au}$, although they show the same structure. The activities of these interfaces are compared for $\mathrm{CO}$ oxidation and follow the order of $\mathrm{Cu}_{2} \mathrm{O} / \mathrm{Pt}>\mathrm{Cu}_{2} \mathrm{O} / \mathrm{Au}>\mathrm{Cu}_{2} \mathrm{O} / \mathrm{Ag}$. OMI is found to determine the activity and stability of supported $\mathrm{Cu}_{2} \mathrm{O} N S$, which could be described by the formation energy of interfacial oxygen vacancy. Further, electronic interaction between $\mathrm{Cu}^{+}$and metal substrates is found center to $\mathrm{OMI}$, where the $d$ band center could be used as a key descriptor. Our study provides insight for OMI and for the development of Cu-based catalysts for low temperature oxidation reactions.

\footnotetext{
${ }^{1}$ State Key Laboratory of Catalysis, Dalian Institute of Chemical Physics, Chinese Academy of Sciences, 116023 Dalian, China. ${ }^{2}$ University of Chinese Academy of Sciences, 100049 Beijing, China. ${ }^{3}$ State Key Laboratory of Physical Chemistry of Solid Surfaces, iChEM, College of Chemistry and Chemical Engineering, Xiamen University, 361005 Xiamen, China. ${ }^{4}$ School of Physical Science and Technology, ShanghaiTech University, 201210 Shanghai, China. ${ }^{5}$ State Key Laboratory of Functional Materials for Informatics, Shanghai Institute of Microsystem and Information Technology, Chinese Academy of Sciences, 200050 Shanghai, China. ${ }^{6}$ Present address: College of Chemistry and Chemical Engineering, Chongqing University, 400044 Chongqing, China. ${ }^{7}$ These authors contributed equally: Wugen Huang, Qingfei Liu. ${ }_{\text {email: fyang@dicp.ac.cn }}$
} 
$\mathrm{M}$ etal alloy catalysts ${ }^{1}$ are widely used for technical applications in chemical industry ${ }^{2,3}$, environmental remediation ${ }^{4}$, and energy conversion ${ }^{5}$. These alloy catalysts usually consist of a precious metal component and a cheap metal component, the latter of which would segregate to the surface under oxidative conditions to form a self-limited oxide layer ${ }^{6}$. Such phenomena have been utilized recently for the controlled synthesis of two-dimensional (2D) oxide layer ${ }^{7}$. In catalysis, studies on the formation of interfacial oxide layer on precious metal surfaces could be traced back to the discovery of strong metal support interaction $(\mathrm{SMSI})^{8}$ and nowadays increasingly found for metal alloy catalysts in catalytic oxidation reactions center for industrial catalysis. Despite tremendous interest, atomic understanding on the catalytic nature of these oxide layers remains a long-standing challenge because interfacial sites are minority surface sites and difficult to access. Nevertheless, the unique catalytic properties of the oxide-metal interface ${ }^{9-13}$ have now been recognized, although how oxide-metal interaction (OMI) tunes the properties of interfacial sites remains largely unknown.

The interface between cuprous oxide and metal has been a system of particular catalytic interest, but difficult to study owing to the dynamic nature of copper centers ${ }^{14}$, i.e., their valence states and coordination numbers vary with the reaction environment. Coordinatively unsaturated (CUS) metal cations have often been found as active sites for catalytic reactions. For instance, CUS $\mathrm{Cu}^{+}$centers are active sites for the oxidation of ethylbenzene to acetophenone ${ }^{15}$. Owing to the stability and activity requirements of technological applications, stabilizing CUS centers on precious metal surfaces has been developed as an effective strategy, as demonstrated by interface-confined ferrous centers for the preferential oxidation reaction ${ }^{12}$. Indeed, the alloy between $\mathrm{Cu}$ and group VIII metals ${ }^{16-20}$, especially $\mathrm{Pt}$, are excellent catalysts for oxygen reduction reaction, whereas alloy catalysts consisting of copper and group IB metals ${ }^{21-23}$ exhibit remarkable performances for the selective oxidation of hydrocarbons. Meanwhile, the formation of a copper oxide-metal interface has been generally observed on $\mathrm{PtCu}^{24}, \mathrm{AuCu}^{25}$, and $\mathrm{AgCu}^{26}$ during oxidation reactions even under mild conditions. Undoubtedly, an atomicscale understanding on the catalytic properties of the $\mathrm{Cu}_{2} \mathrm{O}$-metal $\left(\mathrm{Cu}_{2} \mathrm{O}-\mathrm{M}\right)$ interface is essential to the design and improvement of $\mathrm{Cu}$-based alloy catalysts for oxidation reactions.

Here, we synthesize well-defined $\mathrm{Cu}_{2} \mathrm{O}$ NSs on $\mathrm{Pt}(111), \mathrm{Au}$ (111), and $\operatorname{Ag}(111)$, and study their interfacial structures and chemistry using the combination of low-temperature scanning tunneling microscopy (LT-STM), near-ambient-pressure STM (NAP-STM), X-ray photoelectron spectroscopy (XPS), and density functional theory (DFT) calculations. The atomic structures of interfacial sites are identified unambiguously with elementspecific STM (ES-STM) images. Despite the same interfacial site structure, the activities of the $\mathrm{Cu}_{2} \mathrm{O} / \mathrm{Pt}, \mathrm{Cu}_{2} \mathrm{O} / \mathrm{Au}$, and $\mathrm{Cu}_{2} \mathrm{O} / \mathrm{Ag}$ interfaces for $\mathrm{CO}$ oxidation are found strongly dependent on OMI, where $\mathrm{Cu}_{2} \mathrm{O} / \mathrm{Pt}$ and $\mathrm{Cu}_{2} \mathrm{O} / \mathrm{Au}$ are found to exhibit a reversible structural dynamics during the redox reaction at low temperatures. Our study unravels key factor in determining OMI, and subsequently the activity and stability of supported $\mathrm{Cu}_{2} \mathrm{O}$ NSs, which furthers our understanding on OMI and provides insight for the development of metal alloy catalysts.

\section{Results}

Atomic structures of $\mathrm{Cu}_{2} \mathrm{O}$ NSs on metal substrates. $\mathrm{Cu}_{2} \mathrm{O}$ NSs were synthesized on $\mathrm{Pt}(111), \operatorname{Au}(111)$, and $\operatorname{Ag}(111)$ using the method described in the experimental section and display various sizes with monolayer (ML) thickness (Supplementary Fig. 1). Their atomic structures, both on the surface and at the step edge, could be clearly identified by ES-STM images ${ }^{27-29}$ (Fig. 1). In the $\mathrm{Cu}$-mode STM image, $\mathrm{Cu}$ atoms were resolved as bright dots and exhibit a kagome (trihexagonal stacking) lattice. In the O-mode STM image, $\mathrm{O}$ atoms were imaged as protrusions and display a hexagonal lattice. Combining the $\mathrm{Cu}$-mode and O-mode STM images, these $\mathrm{Cu}_{2} \mathrm{O}$ NSs are found to display a $\mathrm{Cu}_{2} \mathrm{O}(111)$-like structure, which exhibits the honeycomb lattice of $\mathrm{Cu}_{2} \mathrm{O}(111)$ (Fig. 1j), but does not have dangling $\mathrm{Cu}$ atoms at the center of honeycomb, owing to their instability on metal substrates (Fig. 1k). The honeycomb lattice of these $\mathrm{Cu}_{2} \mathrm{O}$ NSs on $\mathrm{Pt}(111)$, $\mathrm{Au}(111)$, or $\mathrm{Ag}(111)$ displays the unit cell length $(\sim 6.0 \AA)$ same as that of $\mathrm{Cu}_{2} \mathrm{O}(111)$. But, due to the missing of dangling $\mathrm{Cu}$ atoms, supported $\mathrm{Cu}_{2} \mathrm{O}$ NSs exhibit the stoichiometry of $\mathrm{Cu}_{3} \mathrm{O}_{2}$, which has been generally observed for $\mathrm{ML} \mathrm{Cu}_{2} \mathrm{O}$ NSs grown on metal substrates 27,30 .

In the surface lattice of $\mathrm{Cu}_{2} \mathrm{O}$ NSs, 5-7 topological defects ${ }^{30}$ could also be observed, especially for $\mathrm{Cu}_{2} \mathrm{O}$ NSs supported on $\mathrm{Ag}$ (111) (Fig. 1g). These 5-7 topological defects were formed via the Stone-Wales type transformation of the $\mathrm{Cu}_{3} \mathrm{O}_{2}$ honeycomb lattice, which has been discussed previously ${ }^{30}$. After the annealing in ultrahigh vacuum (UHV), the step edges of $\mathrm{Cu}_{2} \mathrm{O}$ NSs on $\mathrm{Pt}$ (111), $\mathrm{Au}(111)$, and $\mathrm{Ag}(111)$ also exhibited dominantly the same O-terminated zig-zag structure, as identified by ES-STM images (Fig. 1 and Supplementary Fig. 2). On Au(111), we have shown that the O-terminated zig-zag step is thermodynamically favored ${ }^{27}$ and would become the dominant step structure after the annealing at $600 \mathrm{~K}$, which also appears to be the case for Pt (111) and $\mathrm{Ag}(111)$.

Although $\mathrm{Cu}_{2} \mathrm{O}$ NSs on $\mathrm{Pt}(111), \mathrm{Au}(111)$, and $\mathrm{Ag}(111)$ show the same surface and step structures, their stability was found to be influenced by $\mathrm{OMI}^{31}$. We found that $\mathrm{Cu}_{2} \mathrm{O}$ NSs on $\mathrm{Pt}(111)$ would start to decompose at $\sim 470 \mathrm{~K}$ and decompose completely at $\sim 630 \mathrm{~K}$ (Supplementary Fig. 3a, b), which was accompanied by the diffusion of $\mathrm{Cu}$ atoms into the bulk. Since the desorption of atomic oxygen atoms on $\mathrm{Pt}(111)$ would start at above $500 \mathrm{~K}^{32}$, the low stability of $\mathrm{Cu}_{2} \mathrm{O}$ NSs on $\mathrm{Pt}(111)$ seems to suggest that these $\mathrm{Cu}_{2} \mathrm{O}$ NSs could be highly active for $\mathrm{CO}$ oxidation. In contrast, $\mathrm{Cu}_{2} \mathrm{O}$ NSs appeared stable on $\mathrm{Au}(111)$ and $\mathrm{Ag}(111)$ after the annealing at $600 \mathrm{~K}$ (Supplementary Fig. 3c, e) although they would start to coalesce and form larger islands after the annealing at $700 \mathrm{~K}$ (Supplementary Fig. 3d, f). Thus, the difference in thermal stability of supported $\mathrm{Cu}_{2} \mathrm{O}$ NSs indicates that interfacial interaction could play a key role in determining their stability and reactivity.

$\mathrm{CO}$ adsorption and reaction at the $\mathrm{Cu}_{2} \mathrm{O}$-metal interface. The adsorption and reaction of $\mathrm{CO}$ were then compared for $\mathrm{Cu}_{2} \mathrm{O}$ NSs on $\mathrm{Pt}(111), \mathrm{Au}(111)$, and $\mathrm{Ag}(111)$. When the $\mathrm{Cu}_{2} \mathrm{O} / \mathrm{Pt}(111)$ surface was exposed to $\mathrm{CO}$ at $78 \mathrm{~K}, \mathrm{CO}$ adsorbed randomly on $\mathrm{Pt}$ (111) and the surface of $\mathrm{Cu}_{2} \mathrm{O}$ NSs remained clean, indicating a weak interaction between $\mathrm{CO}$ and $\mathrm{Cu}_{2} \mathrm{O}$ (Fig. 2a and Supplementary Fig. 4). Continuous $\mathrm{CO}$ exposure at $78 \mathrm{~K}$ could cause the appearance of $\mathrm{CO}$ molecules on the surface domains of $\mathrm{Cu}_{2} \mathrm{O}$ (Fig. 2b). But, analysis of high-resolution STM image showed that these $\mathrm{CO}$ molecules were located dominantly on Pt sites exposed at the center of the hexagonal $\mathrm{Cu}_{2} \mathrm{O}$ rings (Supplementary Fig. 5), owing to the much stronger chemisorption of $\mathrm{CO}$ on $\mathrm{Pt}^{33}$. The large holes of the $\mathrm{Cu}_{2} \mathrm{O}$ rings allow for $\mathrm{CO}$ adsorption on Pt sites even when $\mathrm{Pt}(111)$ is fully covered by $\mathrm{Cu}_{2} \mathrm{O}$.

The CO-covered surface of $\mathrm{Cu}_{2} \mathrm{O} / \mathrm{Pt}(111)$ was then annealed to $300 \mathrm{~K}$ in UHV. Figure $2 \mathrm{c}$ showed the reduction of $\mathrm{Cu}_{2} \mathrm{O}$ NSs by $\mathrm{CO}$, starting from both the surface terrace of $\mathrm{Cu}_{2} \mathrm{O}$ and the step edges of $\mathrm{Cu}_{2} \mathrm{O}$. From the development of reaction front, the reaction rate of $\mathrm{Cu}_{2} \mathrm{O}$ reduction from the step edges of $\mathrm{Cu}_{2} \mathrm{O}$ was found to be faster ( 1.3 times) than that on the surface terrace of 

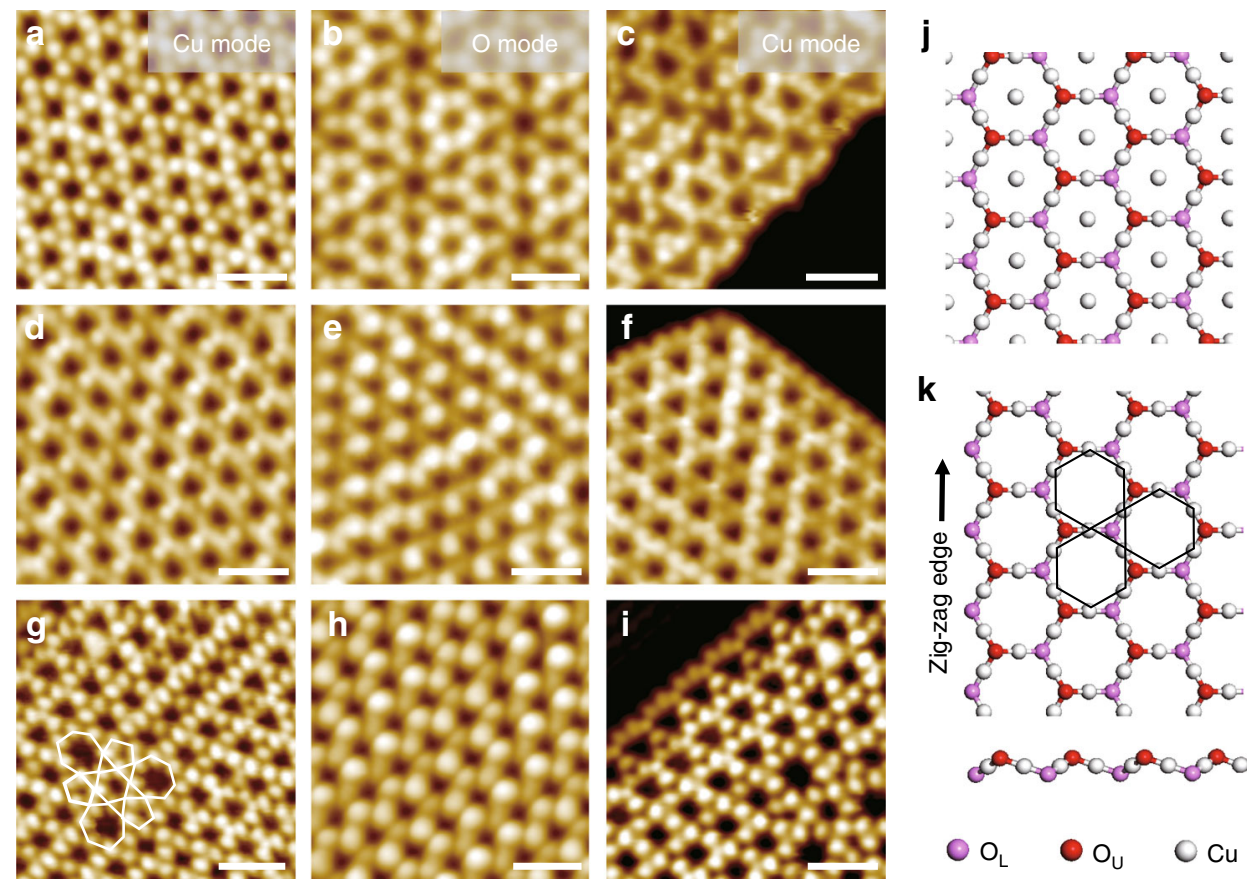

Fig. 1 Element-specific STM images of $\mathbf{C u}_{\mathbf{2}} \mathbf{O}$ NSs grown on metal substrates. a-i STM images of a-c $\mathrm{Cu}_{2} \mathrm{O} / \mathrm{Pt}(111)$, $\mathbf{d}-\mathbf{f} \mathrm{Cu}_{2} \mathrm{O} / \mathrm{Au}(111)$, and $\mathbf{g}-\mathbf{i} \mathrm{Cu} \mathrm{u}_{2} \mathrm{O} / \mathrm{Ag}$ (111). The surface structures of $\mathrm{Cu}_{2} \mathrm{O}$ NSs are displayed in the left column ( $\mathrm{Cu}$-mode: $\mathrm{Cu}$ atoms were resolved as bright dots) and the middle column (O mode: $\mathrm{O}$ atoms were resolved as bright protrusions) of STM images. The edge structures of $\mathrm{Cu}_{2} \mathrm{O}$ NSs are displayed in the right column (Cu-mode) of STM images showing zig-zag step structure with oxygen termination. 5-7 defects in $\mathrm{Cu}_{2} \mathrm{O}$ NS on $\mathrm{Ag}(111)$ are marked by white lines in $\mathbf{g}$. $\mathbf{j}$ The structural model of $\mathrm{Cu}_{2} \mathrm{O}(111)$ surface. $\mathbf{k}$ The structural model of supported $\mathrm{Cu}_{2} \mathrm{O}$ NSs in a-i. $\mathrm{O}_{U}$ and $\mathrm{O}_{\mathrm{L}}$ represent the upper $\mathrm{O}$ and lower $\mathrm{O}$, respectively. All $\mathrm{Cu}_{2} \mathrm{O}$ NSs exhibit the hexagonal lattice of $\mathrm{Cu}_{2} \mathrm{O}$ (111) without dangling $\mathrm{Cu}$ atoms at the center of honeycomb and with an oxygen-terminated zig-zag edge. Scanning parameters: a $V_{\mathrm{s}}=-0.4 \mathrm{~V}, I=1.1 \mathrm{nA} ; \mathbf{b} V_{\mathrm{s}}=-0.2 \mathrm{~V}, I=1.4 \mathrm{nA} ; \mathbf{c} V_{\mathrm{s}}=-0.05 \mathrm{~V}, I=3.0 \mathrm{nA} ; \mathbf{d} V_{\mathrm{s}}=-0.2 \mathrm{~V}, I=1.5 \mathrm{nA} ; \mathbf{e} V_{\mathrm{s}}=-1.15 \mathrm{~V}, I=1.2 \mathrm{nA} ;$ f $V_{\mathrm{s}}=-0.1 \mathrm{~V}, I=2.1 \mathrm{nA} ; \mathbf{g} V_{\mathrm{s}}=-0.32 \mathrm{~V}, I=0.79 \mathrm{nA} ; \mathbf{h} V_{\mathrm{s}}=0.5 \mathrm{~V}, I=0.1 \mathrm{nA} ; \mathbf{i} V_{\mathrm{s}}=-0.32 \mathrm{~V}, I=0.79 \mathrm{nA}$. Scale bars: $1 \mathrm{~nm}$ for all images.

$\mathrm{Cu}_{2} \mathrm{O}$ (Supplementary Fig. 6). The faster reduction rate along the steps of $\mathrm{Cu}_{2} \mathrm{O}$ could be attributed to the lower coordination numbers of $\mathrm{O}$ atoms at step edges. Nonetheless, $\mathrm{CO}$ oxidation at both the step edge and the surface terrace of $\mathrm{Cu}_{2} \mathrm{O}$ occurred via an interfacial dual-site reaction mechanism, i.e., $\mathrm{CO}$ adsorbed on Pt sites to react with neighboring lattice oxygen in $\mathrm{Cu}_{2} \mathrm{O}$.

Consistently, when the $\mathrm{Cu}_{2} \mathrm{O} / \mathrm{Pt}(111)$ surface was exposed to $\mathrm{CO}$ at $300 \mathrm{~K}$, the reduction of $\mathrm{Cu}_{2} \mathrm{O}$ could start right upon the exposure to $5 \times 10^{-8} \mathrm{mbar} \mathrm{CO}$ and the exposure to $1 \times 10^{-7}$ mbar $\mathrm{CO}$ for $5 \mathrm{~min}$ at $300 \mathrm{~K}$ could lead to the complete decomposition of $\mathrm{Cu}_{2} \mathrm{O}$ layer into metallic $\mathrm{Cu}$ atoms or triangular $\mathrm{Cu}_{3} \mathrm{O}_{\mathrm{x}}$ clusters (Fig. 2d-e). These $\mathrm{Cu}_{3} \mathrm{O}_{\mathrm{x}}$ clusters sit on a metallic layer with its apparent height ( $2 \AA$, Supplementary Fig. 7) approximating the step height of $\mathrm{Cu}(111)$. The metallic layer exhibited a hexagonal lattice with a non-uniform lattice spacing $(\sim 5 \AA)$, which is approximately twice that of $\mathrm{Cu}(111)$ and indicating the formation of a $\mathrm{PtCu}_{3}$ alloy (Supplementary Fig. 7d). The exothermic reaction of $\mathrm{CO}$ oxidation could facilitate the alloying between $\mathrm{Cu}$ and $\mathrm{Pt}$ since the formation of $\mathrm{PtCu}_{3}$ is a thermodynamically favored process ${ }^{34}$. Accordingly, XPS O $1 s$ spectra (Fig. $2 \mathrm{f}$ ) showed that only $\sim 10 \%$ of $\mathrm{Cu}_{2} \mathrm{O}$ was left when $0.6 \mathrm{ML} \mathrm{Cu}_{2} \mathrm{O} / \mathrm{Pt}(111)$ was exposed to $\mathrm{CO}$ at $300 \mathrm{~K}$. $\mathrm{CO}$ exposure also led to the adsorption of $\mathrm{CO}$ on bridge and top sites of $\mathrm{Pt}$ (111), as shown in the $\mathrm{O} 1 s$ spectra $^{35}$. In comparison, when the $\mathrm{Pt}$ (111) surface is fully covered by $\mathrm{Cu}_{2} \mathrm{O}$, the reduction of the $\mathrm{Cu}_{2} \mathrm{O}$ layer requires a higher $\mathrm{CO}$ pressure at $5 \times 10^{-6} \mathrm{mbar}$ (Supplementary Fig. 8). The major problem that prevents Pt group metals from catalyzing low temperature $\mathrm{CO}$ oxidation is the strong chemisorption (poisoning) of CO blocks surface sites for the adsorption and activation of $\mathrm{O}_{2}$. The superior activity of supported $\mathrm{Cu}_{2} \mathrm{O}$ NSs demonstrated above showed that such problem could be annihilated by the formation of a $\mathrm{Cu}_{2} \mathrm{O} / \mathrm{Pt}$ interface.

In comparison, when the $\mathrm{Cu}_{2} \mathrm{O} / \mathrm{Au}(111)$ surface was exposed to $\mathrm{CO}$ at $78 \mathrm{~K}$ (Fig. 3a, b), no adsorption of $\mathrm{CO}$ molecules was obvious in STM and $\mathrm{Cu}_{2} \mathrm{O}$ NSs remained intact. While $\mathrm{CO}$ molecules could adsorb on bulk $\mathrm{Cu}_{2} \mathrm{O}$ surfaces at cryogenic temperatures ${ }^{36}$, the interaction between $\mathrm{CO}$ and supported $\mathrm{Cu}_{2} \mathrm{O}$ NSs appeared to be much weakened by OMI. Owing to the weak interaction between $\mathrm{CO}$ and $\mathrm{Cu}_{2} \mathrm{O} / \mathrm{Au}(111), \mathrm{CO}$ exposure under vacuum conditions did not cause any change on the $\mathrm{Cu}_{2} \mathrm{O} / \mathrm{Au}$ (111) surface at $300 \mathrm{~K}$. However, as the partial pressure of $\mathrm{CO}$ was raised to 0.5 mbar, enhanced $\mathrm{CO}$ adsorption could cause the continuous reduction of $\mathrm{Cu}_{2} \mathrm{O}$ NSs to form the $\mathrm{Cu}-\mathrm{Au}$ surface alloy (Fig. 3c-h). In situ NAP-STM images showed further that the reduction started from the edges of $\mathrm{Cu}_{2} \mathrm{O}$ NSs on $\mathrm{Au}(111)$ (Supplementary Fig. 9). When the $\mathrm{Au}(111)$ surface was fully covered by $\mathrm{Cu}_{2} \mathrm{O}$, the onset pressure for the reduction of the $\mathrm{Cu}_{2} \mathrm{O}$ layer needs be further raised to $\sim 6$ mbar $\mathrm{CO}$ in our NAPSTM study. Thus, both the activity and the stability of supported $\mathrm{Cu}_{2} \mathrm{O}$ NSs are influenced by OMI.

While $\mathrm{CO}$ oxidation occurred readily at the $\mathrm{Cu}_{2} \mathrm{O} / \mathrm{Pt}(111)$ and the $\mathrm{Cu}_{2} \mathrm{O} / \mathrm{Au}(111)$ interface under UHV and NAP conditions, respectively, no appreciable activities of $\mathrm{CO}$ oxidation were observed on the $\mathrm{Cu}_{2} \mathrm{O} / \mathrm{Ag}(111)$ surface in $10 \mathrm{mbar} \mathrm{CO}$ at $300 \mathrm{~K}$ (Fig. 4 and Supplementary Fig. 10), despite $\mathrm{Cu}_{2} \mathrm{O}$ exposes the same zig-zag edge structure on $\mathrm{Ag}(111)$ as those on $\mathrm{Pt}(111)$ and $\mathrm{Au}(111)$ and the adsorption energy of $\mathrm{CO}$ on $\mathrm{Ag}(111)$ is similar to that on $\mathrm{Au}(111)^{37}$. Indeed, even when $\mathrm{CO}$ pressure was raised to $\sim 48$ mbar, the zig-zag edges of $\mathrm{Cu}_{2} \mathrm{O}$ on $\mathrm{Ag}(111)$ could not react with $\mathrm{CO}$ at $300 \mathrm{~K}$, whereas one could start to observe the reduction of $\mathrm{Cu}_{2} \mathrm{O}$ from low-coordination sites at the domain 

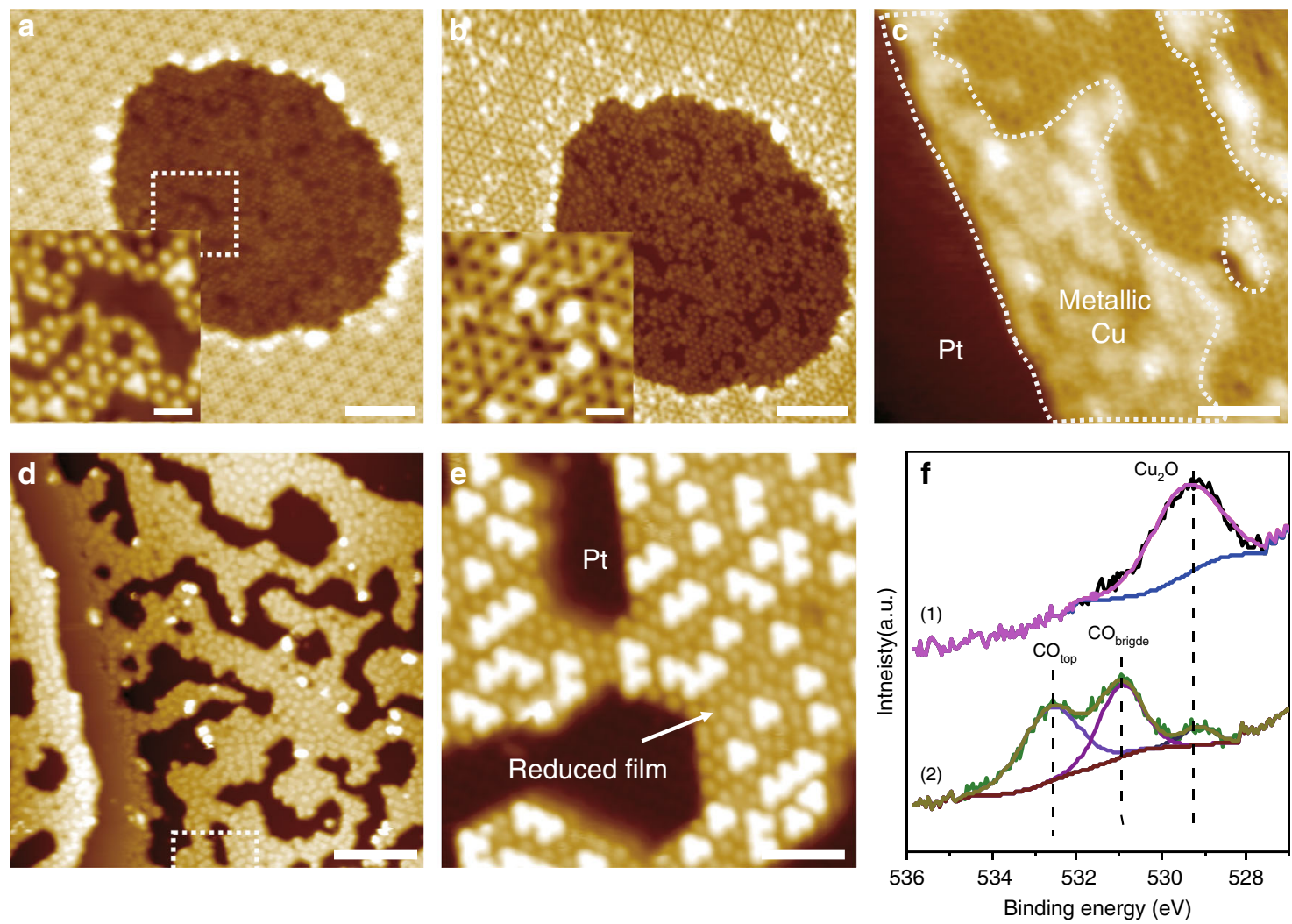

Fig. 2 The adsorption and reaction of $\mathbf{C O}$ on $\mathbf{C u}_{\mathbf{2}} \mathbf{O} / \mathbf{P t}(\mathbf{1 1 1})$. $\mathbf{a}$, $\mathbf{b}$ In situ STM images of the $\mathrm{Cu}_{2} \mathrm{O} / \mathrm{Pt}(111)$ surface during the exposure to $\mathrm{CO}$ at $78 \mathrm{~K}$. The squared region in $\mathbf{a}$ is magnified in inset, showing $\mathrm{CO}$ adsorption on a $\mathrm{Pt}(111)$ surface covered by $(2 \times 2)-\mathrm{O}$. Inset in $\mathbf{b}$ displays the adsorption sites of $\mathrm{CO}$ on $\mathrm{Cu}_{2} \mathrm{O}$, which are centered at the holes of the $\mathrm{Cu}_{2} \mathrm{O}$ rings. $\mathbf{c}$ STM image of the partially reduced $\mathrm{Cu}_{2} \mathrm{O} / \mathrm{Pt}(111)$ surface after the surface in $\mathbf{b}$ was annealed to $300 \mathrm{~K}$. The reduction by $\mathrm{CO}$ started from both the step edge and the surface of $\mathrm{Cu}_{2} \mathrm{O}$. The dotted curves indicate the regions of metallic $\mathrm{Cu}$. $\mathbf{d}$, e STM images of a $\mathrm{Cu}_{2} \mathrm{O} / \mathrm{Pt}(111)$ surface after the exposure to $1 \times 10^{-7} \mathrm{mbar} \mathrm{CO}$ for $5 \mathrm{~min}$ at $300 \mathrm{~K}$. High-resolution STM image (e) from the marked area in d shows the reduction of $\mathrm{Cu}_{2} \mathrm{O}$ by $\mathrm{CO}$ led to the formation of triangular $\mathrm{Cu}_{3} \mathrm{O}_{\mathrm{x}}$ clusters, sitting on a metallic layer. $\mathbf{f} \times \mathrm{PS} \mathrm{O} 1 \mathrm{~s} \mathrm{spectra}$ of the $\mathrm{Cu}_{2} \mathrm{O} / \mathrm{Pt}(111)$ surface before (1) and after (2) the exposure to $1.2 \times 10^{-7} \mathrm{mbar} C \mathrm{O}$ for $5 \mathrm{~min}$ at $300 \mathrm{~K}$. Lattice $\mathrm{O}$ of $\mathrm{Cu}_{2} \mathrm{O}$ with binding energy at $529.4 \mathrm{eV}$ has been mostly consumed after $\mathrm{CO}$ exposure, accompanying the adsorption of $\mathrm{CO}$ on top sites $\left(\mathrm{CO}_{\text {top }}\right)$ and bridge sites $\left(\mathrm{CO}_{\text {bridge}}\right)$ of the exposed Pt surface. Scanning parameters: $\mathbf{b} V_{\mathrm{s}}=-0.3 \mathrm{~V}, I=0.2 \mathrm{nA}$; inset: $V_{\mathrm{s}}=-0.3 \mathrm{~V}, I=0.5 \mathrm{nA} ; \mathbf{c} V_{\mathrm{s}}=-0.15 \mathrm{~V}, I=1.2 \mathrm{nA}$; e $V_{\mathrm{s}}=-0.15 \mathrm{~V}, I=0.5 \mathrm{nA}$. Scale bars: a, b $5 \mathrm{~nm}$, inset 1 $\mathrm{nm} ; \mathbf{c} 3 \mathrm{~nm} ; \mathbf{d} 10 \mathrm{~nm} ; \mathbf{e} 2 \mathrm{~nm}$.
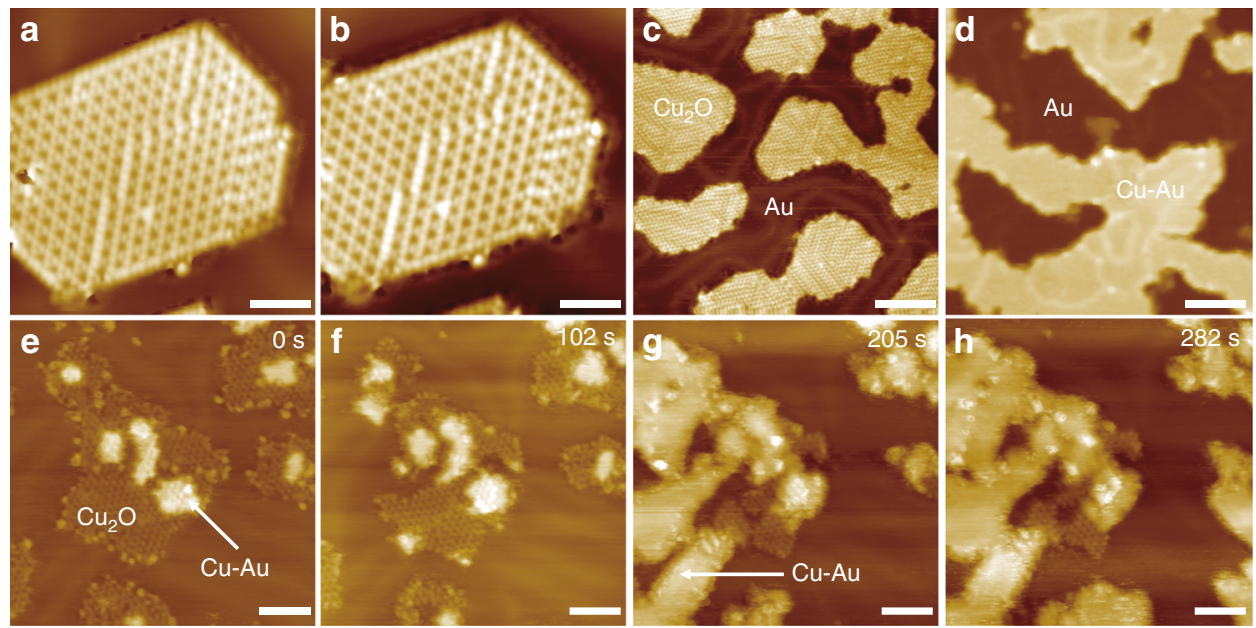

Fig. 3 The adsorption and reaction of $\mathbf{C O}$ on $\mathbf{C u}_{\mathbf{2}} \mathbf{O} / \mathbf{A u}(\mathbf{1 1 1})$. $\mathbf{a}, \mathbf{b}$ In situ STM images before (a) and after (b) the exposure of $\mathrm{CO}$ on $\mathrm{Cu} 2 \mathrm{O} / \mathrm{Au}(111)$ at $78 \mathrm{~K}$. No adsorption was obvious after the exposure of $18 \mathrm{~L} \mathrm{CO}$. c, $\mathbf{d}$ Ex-situ and $\mathbf{e}-\mathbf{h}$ in situ NAP-STM images on the reduction of $\mathrm{Cu}_{2} \mathrm{O}$ on $\mathrm{Au}(111)$ in $1 \mathrm{mbar}$ (d) or $0.5 \mathrm{mbar}(\mathbf{e}-\mathbf{h}) \mathrm{CO}$ at $300 \mathrm{~K}$. The reduction of $\mathrm{Cu}_{2} \mathrm{O}$ NSs led to the formation of a $\mathrm{Cu}-\mathrm{Au}$ surface alloy. The reaction times were marked at the top right of images. Scanning parameters: a $V_{\mathrm{s}}=-2.0 \mathrm{~V}, I=0.06 \mathrm{nA} ; \mathbf{b} V_{\mathrm{s}}=-1.7 \mathrm{~V}, I=0.03 \mathrm{nA} ; \mathbf{c} V_{\mathrm{s}}=1.1 \mathrm{~V}, I=0.09 \mathrm{nA} ; \mathbf{e} V_{\mathrm{s}}=1.2 \mathrm{~V}, I=0.02 \mathrm{nA}$; f $V_{\mathrm{s}}=1.2 \mathrm{~V}, \mathrm{I}=0.05 \mathrm{nA}$. Scale bars: a, b $2 \mathrm{~nm}$; c, d $10 \mathrm{~nm}$; e-h $5 \mathrm{~nm}$. 

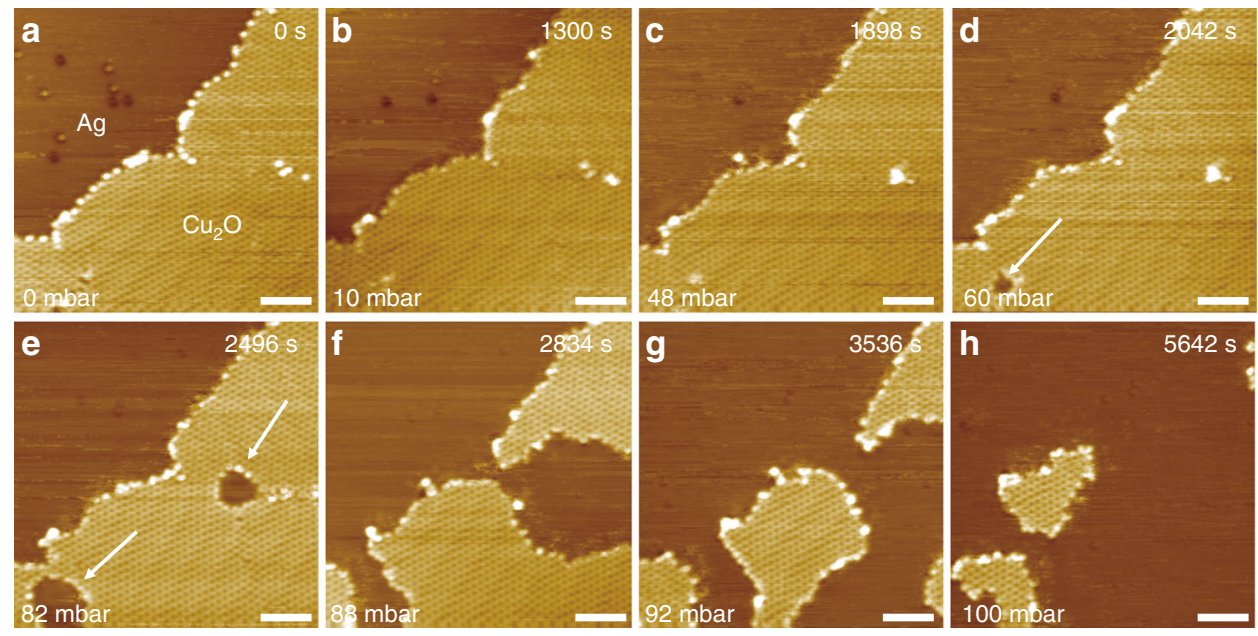

Fig. 4 Reaction of $\mathbf{C O}$ on $\mathbf{C u}_{\mathbf{2}} \mathbf{O} / \mathbf{A g ( 1 1 1 )}$. $\mathbf{a}-\mathbf{h}$ In situ NAP-STM images on the reduction of the $\mathrm{Cu}_{2} \mathrm{O} / \mathrm{Ag}(111)$ surface under elevated $\mathrm{CO}$ pressures from 0 to $100 \mathrm{mbar}$ at $300 \mathrm{~K}$. Reduction of the $\mathrm{Cu}_{2} \mathrm{O}$ layer was observed in $>48 \mathrm{mbar} \mathrm{CO}$, starting from domain boundaries indicated by white arrows in $\mathbf{d}$, e. The pressures of $\mathrm{CO}$ were labeled at the bottom left of STM images, and reaction times were labeled at the top right of images. Scanning parameters: a-h $V_{\mathrm{s}}=$ $0.9 \mathrm{~V}, I=0.1 \mathrm{nA}$. Scale bars: $5 \mathrm{~nm}$ for all images.

boundaries of $\mathrm{Cu}_{2} \mathrm{O}$. The inactivity of the zig-zag edges of $\mathrm{Cu}_{2} \mathrm{O}$ on $\mathrm{Ag}(111)$ is in drastic contrast to the active zig-zag edges of $\mathrm{Cu}_{2} \mathrm{O}$ on $\mathrm{Au}(111)$ and $\mathrm{Pt}(111)$, where the onset reaction pressures are in the ranges of $10^{-1}$ and $10^{-8} \mathrm{mbar} \mathrm{CO}$, respectively. Thus, the reactivity trend of the $\mathrm{Cu}_{2} \mathrm{O} / \mathrm{M}$ interface follows the order of: $\mathrm{Cu}_{2} \mathrm{O} / \mathrm{Pt}(111)>\mathrm{Cu}_{2} \mathrm{O} / \mathrm{Au}(111)>\mathrm{Cu}_{2} \mathrm{O} / \mathrm{Ag}(111)$. Note that, the rate equation could be affected by both the surface coverage of $\mathrm{CO}$ and the activation energy. Since the adsorption energies of $\mathrm{CO}$ are approximately similar $(-0.29 \mathrm{eV})^{37}$ on $\mathrm{Au}(111)$ and $\mathrm{Ag}$ (111), the reactivity comparison between $\mathrm{Cu}_{2} \mathrm{O} / \mathrm{Au}(111)$ and $\mathrm{Cu}_{2} \mathrm{O} / \mathrm{Ag}(111)$ could indeed rule out influence of surface $\mathrm{CO}$ coverage and corroborated further the critical role of OMI in tuning the activation barrier and thus reactivity of the oxide-metal interface.

The regeneration of $\mathrm{Cu}_{2} \mathrm{O}$ NSs is important to complete the catalytic cycle of $\mathrm{CO}$ oxidation. We found that the re-oxidation of the $\mathrm{Pt}-\mathrm{Cu}$ surface alloy on $\mathrm{CO}$-covered $\mathrm{Pt}(111)$ requires only an $\mathrm{O}_{2}$ atmosphere at $5 \times 10^{-8} \mathrm{mbar}$ (at $>400 \mathrm{~K}$ ) to form well-ordered $\mathrm{Cu}_{2} \mathrm{O}$ NSs (Supplementary Fig. 11a), whereas the $\mathrm{Au}-\mathrm{Cu}$ surface alloy remained metallic in $5 \times 10^{-7}$ mbar $\mathrm{O}_{2}$ at $450 \mathrm{~K}$ (Supplementary Fig. 11b). But, $\mathrm{Cu}_{2} \mathrm{O}$ NSs were found to grow from the steps of the $\mathrm{Au}-\mathrm{Cu}$ surface alloy on $\mathrm{Au}(111)$ in $~ 1 \mathrm{mbar}$ $\mathrm{O}_{2}$ at $300 \mathrm{~K}$ (Supplementary Fig. 11c). Similarly, $\mathrm{Cu}$ on $\mathrm{Ag}(111)$ could be oxidized into $\mathrm{Cu}_{2} \mathrm{O}$ in 0.17 mbar $\mathrm{O}_{2}$, accompanying the oxidation of $\mathrm{Ag}(111)$ (Supplementary Fig. 11d). In this case, $\mathrm{CO}$ oxidation on the $\mathrm{Cu}_{2} \mathrm{O} / \mathrm{Ag}(111)$ surface could be a convoluted process since $\mathrm{Ag}(111)$ could also be oxidized by $\mathrm{O}_{2}$ under NAP conditions ${ }^{38}$. Yet, the redox cycle of supported $\mathrm{Cu}_{2} \mathrm{O}$ NSs should exhibit a lower barrier on $\mathrm{Pt}(111)$ than on $\mathrm{Au}(111)$ and $\mathrm{Ag}(111)$. Although group IB precious metals do not suffer from the COpoisoning problem, their weak interaction with $\mathrm{CO}$ and $\mathrm{O}_{2}{ }^{39,40}$ are not favorable for maintaining an active $\mathrm{Cu}_{2} \mathrm{O}$-metal interface, which appears crucial for a sustained catalytic activity in low temperature $\mathrm{CO}$ oxidation. Owing to the strong chemisorption of $\mathrm{CO}$ on Pt group metals, the presence of excess $\mathrm{O}_{2}$ or the increase of reaction temperature should be beneficial to sustain the active $\mathrm{Cu}_{2} \mathrm{O}$-metal interface for $\mathrm{CO}$ oxidation.

Catalytic performance for $\mathrm{CO}$ oxidation. To examine the role of OMI in tuning the catalytic activity of supported $\mathrm{Cu}_{2} \mathrm{O}$ NSs, we prepared further $\mathrm{PtCu}, \mathrm{AuCu}$ and $\mathrm{AgCu}$ alloy nanoparticle catalysts supported on carbon black (CB) and measured their catalytic performances in $\mathrm{CO}$ oxidation as a function of temperature and under $\mathrm{O}_{2}$-rich conditions (oxide supports were avoided to reduce the complexity of interfacial interaction). Previous studies ${ }^{24,26,41}$ have shown that $\mathrm{Cu}$ atoms in bimetallic nanoparticles would segregate to the surface to form oxide layer under oxidative conditions, which is typical for cheap metals in bimetallic alloys ${ }^{6,12,42}$. The chemical states of these catalysts were confirmed further in the post-reaction analysis using quasi-in situ XPS (Supplementary Fig. 12), where the XPS chamber is attached with a high-pressure reactor for catalytic studies. XPS measurements showed that, after reaction, $\mathrm{Cu}$ in the $\mathrm{PtCu} / \mathrm{CB}$ and $\mathrm{AuCu} /$ $\mathrm{CB}$ catalysts remained as $\mathrm{Cu}_{2} \mathrm{O}$ from the $\mathrm{Cu} 2 p$ and $\mathrm{Cu}$ Auger spectra ${ }^{43}$, whereas $\mathrm{Cu}$ in the $\mathrm{AgCu} / \mathrm{CB}$ catalyst was oxidized into $\mathrm{CuO}$. The size and structure of alloy nanoparticle catalysts were examined by transmission electron microscopy (TEM, Supplementary Fig. 13). The particle morphology appeared similar before and after reaction, except that the ripening of particles could be observed.

Figure 5 compared the light-off curves of the series of catalysts in $\mathrm{CO}$ oxidation, where the catalytic performances of $\mathrm{Cu}_{2} \mathrm{O}$ powders and $\mathrm{Pt}, \mathrm{Au}$, and $\mathrm{Ag}$ nanoparticles supported on $\mathrm{CB}$ (denoted as $\mathrm{Pt} / \mathrm{CB}, \mathrm{Au} / \mathrm{CB}$, and $\mathrm{Ag} / \mathrm{CB}$, respectively) were also measured for comparison. Consistent with the above model studies, the $\mathrm{PtCu} / \mathrm{CB}$ catalyst exhibited appreciable activity for $\mathrm{CO}$ oxidation right above $300 \mathrm{~K}$, whereas $\mathrm{Pt} / \mathrm{CB}$ showed neglectable $\mathrm{CO}$ conversion at below the $\mathrm{CO}$ desorption temperature $(\sim 400 \mathrm{~K})^{44}$. The activity of the $\mathrm{AuCu} / \mathrm{CB}$ catalyst is also superior to those of $\mathrm{Cu}_{2} \mathrm{O}$ and $\mathrm{Au} / \mathrm{CB}$ catalysts, and showed activity at above $300 \mathrm{~K}$, although the increase of $\mathrm{CO}$ conversion is slower than that of $\mathrm{PtCu} / \mathrm{CB}$ catalyst. The activities of $\mathrm{AgCu} / \mathrm{CB}$ and $\mathrm{Ag} / \mathrm{CB}$ catalysts (Supplementary Fig. 14) were not plotted with above catalysts for comparison, since the operation of these catalysts did not suffer CO poisoning and involved surface oxidation of $\mathrm{Ag}^{38,45}$ (as evidenced in Supplementary Fig. 11). As $\mathrm{Ag}$ alone showed good activity for $\mathrm{CO}$ oxidation under $\mathrm{O}_{2}$-rich conditions, the formation of $\mathrm{CuO}_{\mathrm{x}} / \mathrm{Ag}$ interface reduced the activity of $\mathrm{Ag}$ for $\mathrm{CO}$ oxidation, which could be attributed to the covering of active Ag sites and consistent with the above STM study. Weak OMI in $\mathrm{Cu}_{2} \mathrm{O} / \mathrm{Ag}$ is insufficient to maintain the active $\mathrm{Cu}^{+}$state, leading to the formation of $\mathrm{CuO}$ (Supplementary Fig. 12) and the decrease of reactivity. By comparison, the formation of $\mathrm{Cu}_{2} \mathrm{O} / \mathrm{M}$ interfaces indeed annihilate the $\mathrm{CO}$ poisoning problem suffered by Pt group metals and the reactivity 


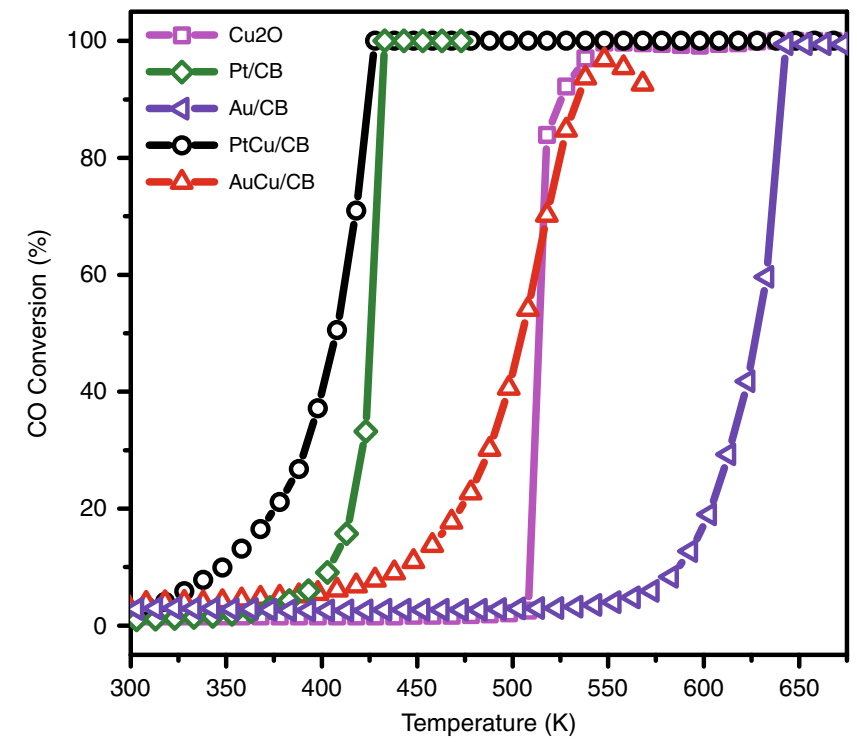

Fig. 5 Catalytic performance of the $\mathrm{PtCu} / \mathrm{CB}, \mathrm{Pt} / \mathrm{CB}, \mathrm{AuCu} / \mathrm{CB}, \mathrm{Au} / \mathrm{CB}$ and $\mathrm{Cu}_{\mathbf{2}} \mathbf{O}$ catalysts. The light-off curves for $\mathrm{CO}$ oxidation were obtained under the condition of $1 \% \mathrm{CO}, 20 \% \mathrm{O}_{2}$, and $79 \% \mathrm{He}$. Space velocity was $60,000 \mathrm{~mL} \mathrm{~g}^{-1} \mathrm{~h}^{-1}$.

from powder catalytic measurements agree with the model studies in the order of: $\mathrm{Cu}_{2} \mathrm{O} / \mathrm{Pt}>\mathrm{Cu}_{2} \mathrm{O} / \mathrm{Au}>\mathrm{Cu}_{2} \mathrm{O} / \mathrm{Ag}$, which again confirmed the activities of $\mathrm{Cu}_{2} \mathrm{O}$ NSs are tuned by OMI.

Analysis on the oxide-metal interaction. Spin-polarized DFT calculations were further conducted to understand the nature of $\mathrm{OMI}$ in tuning the activities of supported $\mathrm{Cu}_{2} \mathrm{O}$ NSs. Based on the atomic structures determined from ES-STM, structural models of $\mathrm{M}(111)$-supported $(\mathrm{M}=\mathrm{Pt}, \mathrm{Au}, \mathrm{Ag})$ and freestanding $\mathrm{Cu}_{8} \mathrm{O}_{6}$ nanoribbons were constructed, denoted as $\mathrm{Cu}_{2} \mathrm{O} / \mathrm{M}$ and $\mathrm{Cu}_{2} \mathrm{O}$-fs. After structural optimization, these models showed the honeycomb lattice of an $\mathrm{O}-\mathrm{Cu}-\mathrm{O}$ tri-layer with $\mathrm{O}$-terminated zig-zag edges (Fig. 6a), consistent with STM results. To understand the above model catalytic studies, we looked into the reaction between $\mathrm{CO}$ and $\mathrm{O}$ of supported $\mathrm{Cu}_{8} \mathrm{O}_{6}$ nanoribbons (Fig. 6b-d). STM study (Supplementary Fig. 6) showed that the reduction of $\mathrm{Cu}_{3} \mathrm{O}_{2}$ occurred mainly at edge $\mathrm{O}$ sites. We thus considered mainly the reaction between $\mathrm{CO}$ and edge $\mathrm{O}$ atoms in supported $\mathrm{Cu}_{8} \mathrm{O}_{6}$ nanoribbons. The energy of $\mathrm{CO}$ in gas phase was corrected as the Gibbs free energy of CO under UHV conditions $\left(1 \times 10^{-7}\right.$ mbar).

For the $\mathrm{Cu}_{2} \mathrm{O} / \mathrm{Au}$ and $\mathrm{Cu}_{2} \mathrm{O} / \mathrm{Ag}$ systems, the Gibbs free energy barrier for transition state 1 (TS1, Fig. 6b, d) corresponds to the energy difference between TS1 and CO in gas phase since CO adsorption is not preferred under UHV conditions and the free energy barrier increases linearly to the decrease of the logarithm of CO pressure (Supplementary Figs. 15, 16). The reaction diagrams (Fig. $6 \mathrm{~b}, \mathrm{~d}$ ) suggested that the rate determining step is the formation of $\mathrm{CO}_{2}$, where the barrier on $\mathrm{Cu}_{2} \mathrm{O} / \mathrm{Pt}(0.42 \mathrm{eV})$ is lower than those on $\mathrm{Cu}_{2} \mathrm{O} / \mathrm{Au}(0.60 \mathrm{eV})$ and $\mathrm{Cu}_{2} \mathrm{O} / \mathrm{Ag}(0.86 \mathrm{eV})$. The high activity of the $\mathrm{Cu}_{2} \mathrm{O} / \mathrm{Pt}$ interface could be interpreted via a dual-site mechanism ${ }^{12,46}$ that $\mathrm{Pt}(111)$ provides proper $\mathrm{CO}$ adsorption while the interface between $\mathrm{Pt}$ and edge $\mathrm{Cu}$ sites enables $\mathrm{O}_{2}$ dissociation (Supplementary Fig. 17) via a low dissociation barrier $(0.39 \mathrm{eV})$, which is also thermodynamically favored. In comparison, $\mathrm{O}_{2}$ dissociation at $\mathrm{Cu}_{2} \mathrm{O} / \mathrm{Au}$ and $\mathrm{Cu}_{2} \mathrm{O}$ / $\mathrm{Ag}$ interfaces are thermodynamically less-favorable, although the process was still enhanced by OMI, when compared with those on $\mathrm{Au}(111)$ and $\operatorname{Ag}(111)^{37}$.
We then look further into geometric and electronic factors that could be utilized to quantify the role of OMI in dictating the activity of $\mathrm{Cu}_{2} \mathrm{O} / \mathrm{M}$ systems. Typically, the adhesion energy $\left(E_{\text {adh }}\right)$ has been used to quantify OMI, which for $\mathrm{Cu}_{8} \mathrm{O}_{6}$ nanoribbon on $\mathrm{M}(111)$, gives the order of $\mathrm{Cu}_{2} \mathrm{O} / \mathrm{Pt}(-0.76 \mathrm{eV})>\mathrm{Cu}_{2} \mathrm{O} / \mathrm{Ag}$ $(-0.71 \mathrm{eV})>\mathrm{Cu}_{2} \mathrm{O} / \mathrm{Au}(-0.58 \mathrm{eV})$. This is obviously inconsistent with the reactivity order observed in the above experimental studies and indicates that the dual interaction of $\mathrm{Cu} / \mathrm{O}$ atoms with $\mathrm{M}(111)$ could be not directly relevant to the key reaction steps, i.e., the formation of $\mathrm{CO}_{2}$ and the subsequent formation of $\mathrm{O}$ vacancy in $\mathrm{Cu}_{2} \mathrm{O}$. In this case, oxygen vacancy formation energy $\left(E_{\text {Ovf }}\right)$ should be of direct relevance and indeed we found the order of $E_{\mathrm{Ovf}}$ for supported $\mathrm{Cu}_{2} \mathrm{O}$ NSs tracks the same order as their catalytic activities $\left(\mathrm{Cu}_{2} \mathrm{O} / \mathrm{Pt}>\mathrm{Cu}_{2} \mathrm{O} / \mathrm{Au}>\mathrm{Cu}_{2} \mathrm{O} / \mathrm{Ag}\right.$, Fig. $\left.6 \mathrm{c}\right)$. Further, compared with $E_{\mathrm{Ovf}}$ on the edge of $\mathrm{Cu}_{2} \mathrm{O}$-fs $(-0.39 \mathrm{eV})$, $E_{\text {Ovf }}$ for supported $\mathrm{Cu}_{2} \mathrm{O}$ NSs are much more negative, in the range of $-1.33 \sim-2.35 \mathrm{eV}$, suggesting the formation of oxygen vacancy is much facilitated at the edges of $\mathrm{Cu}_{2} \mathrm{O} / \mathrm{M}$. Thus, OMI plays a key role in weakening the $\mathrm{Cu}-\mathrm{O}$ bond and facilitating the removal of $\mathrm{O}$ atoms by $\mathrm{CO}$. The stronger $\mathrm{OMI}$, the easier the removal of $\mathrm{O}$ and the formation of $\mathrm{CO}_{2}$.

As we looked into the process of $\mathrm{O}$ removal, the interaction between $\mathrm{M}(111)$ and $\mathrm{Cu}^{+}$(the formation of $\mathrm{Cu}-\mathrm{M}$ bond after the removal of O, Supplementary Fig. 18) is found as a key descriptor for the formation of $\mathrm{O}$ vacancies (Fig. 7). We calculated the projected density of states on $d$ orbitals of $\mathrm{Cu}$ atoms on the edge of $\mathrm{Cu}_{2} \mathrm{O}$-fs and $\mathrm{M}$ atoms from the surface layer of $\mathrm{M}(111)$ clean surface $(\mathrm{M}=\mathrm{Pt}, \mathrm{Au}, \mathrm{Ag})$ and their corresponding $d$ band centers $\left(\varepsilon_{\mathrm{d}}\right.$, Fig. 7a). According to the $d$-band theory 47 , when the $\varepsilon_{\mathrm{d}}$ of $\mathrm{M}$ is closer to the Fermi level, the stronger interaction of metal surface with $\mathrm{Cu}^{+}$could be expected since the $d$ band for $\mathrm{Cu}^{+}$ is relatively localized (molecule like, Fig. 7a). Therefore, the bonding strength between $\mathrm{M}(111)$ and $\mathrm{Cu}^{+}$follows the order of $\mathrm{Cu}_{2} \mathrm{O} / \mathrm{Pt}>\mathrm{Cu}_{2} \mathrm{O} / \mathrm{Au}>\mathrm{Cu}_{2} \mathrm{O} / \mathrm{Ag}$, consistent with the rank order of $E_{\mathrm{Ovf}}$ and the catalytic activity. Quantitatively, we use the distance between $\varepsilon_{\mathrm{d}}$ of $\mathrm{Cu}_{2} \mathrm{O}$ and $\varepsilon_{\mathrm{d}}$ of $\mathrm{M}(111)$ to describe the electronic interaction between $\mathrm{Cu}^{+}$and $\mathrm{M}$. Assuming $\varepsilon_{\mathrm{d}}$ of $\mathrm{Cu}_{2} \mathrm{O}$ at a fixed value, the differences in electronic interaction among $\mathrm{Cu}_{2} \mathrm{O} / \mathrm{M}$ could be represented by the differences in $\varepsilon_{\mathrm{d}}$ of $\mathrm{M}$. As we plotted $E_{\text {Ovf }}$ as a function of $\varepsilon_{\mathrm{d}}$ for $\mathrm{M}(111)$ in Fig. $7 \mathrm{~b}$, an excellent scaling relationship could be observed. Note that, geometric factors, such as surface rumpling $(\Delta h)$, has also been used to describe the formation energy of $\mathrm{O}$ vacancies on oxide surfaces. ${ }^{48}$ But, our study found that surface rumpling cannot be used to describe the $\mathrm{Cu}_{2} \mathrm{O}-\mathrm{M}$ interface, because the order of $\Delta h$ for $\mathrm{Cu}_{8} \mathrm{O}_{6}$ nanoribbons on metal substrates is: $\mathrm{Cu}_{2} \mathrm{O} / \mathrm{Pt}(0.46 \AA)>$ $\mathrm{Cu}_{2} \mathrm{O} / \mathrm{Ag}(0.40 \AA)>\mathrm{Cu}_{2} \mathrm{O} / \mathrm{Au}(0.34 \AA)$, inconsistent with their reactivity order. Therefore, OMI should be described by the electronic interaction between $\mathrm{Cu}_{2} \mathrm{O}$ and metal substrates, where $\varepsilon_{\mathrm{d}}$ could be used as a simple descriptor. Pt group metals are favored over group IB metals for interfacial catalysis of $\mathrm{CO}$ oxidation, due to the much stronger OMI that lowers/stabilizes greatly the reaction energy surfaces. We identify the interaction between $\mathrm{M}(111)$ and $\mathrm{Cu}^{+}$as a key descriptor to quantify the role of OMI in dictating the reactivity of $\mathrm{Cu}_{2} \mathrm{O} / \mathrm{M}$ in $\mathrm{CO}$ oxidation. The stronger interaction of $\mathrm{M}(111)$ with $\mathrm{Cu}^{+}$enables the higher activity of $\mathrm{Cu}_{2} \mathrm{O} / \mathrm{M}$ for catalytic oxidation.

To understand the catalytic properties of the $\mathrm{Cu}_{2} \mathrm{O}-$ metal interface, well-defined $\mathrm{Cu}_{2} \mathrm{O}$ NSs were synthesized on a series of $\mathrm{M}(111)(\mathrm{M}=\mathrm{Pt}, \mathrm{Au}, \mathrm{Ag})$ single crystals and studied at the atomic scale using LT-STM, NAP-STM, XPS, and DFT calculations. The surface and step structures of supported $\mathrm{Cu}_{2} \mathrm{O}$ NSs were identified unambiguously in ES-STM images, which show the same $\mathrm{Cu}_{3} \mathrm{O}_{2}$ honeycomb lattice for the above $\mathrm{Cu}_{2} \mathrm{O}$ NSs, with similar unit cell length and a dominant O-terminated zig-zag edge. Despite their structural similarity, supported $\mathrm{Cu}_{2} \mathrm{O}$ NSs 
a
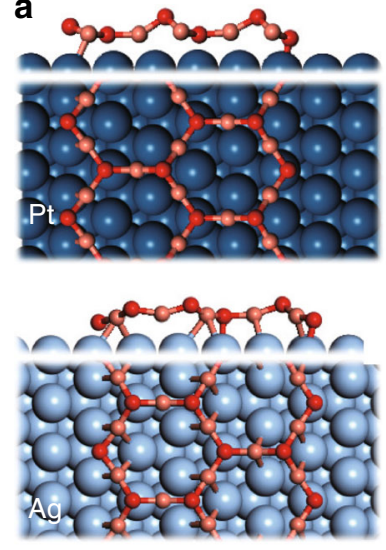

C

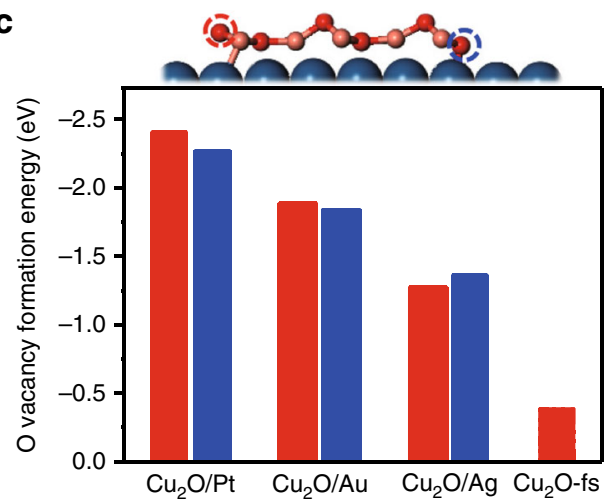

b

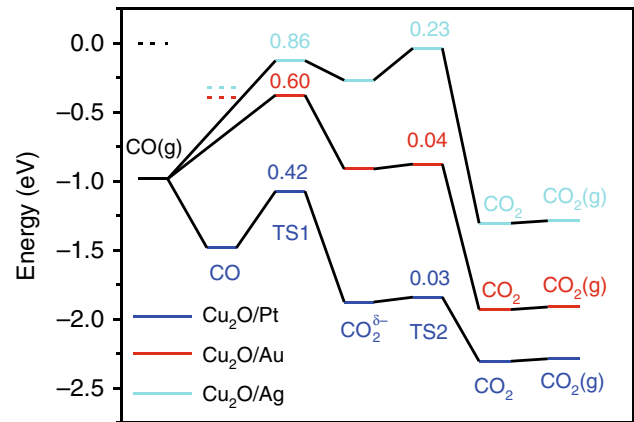

d
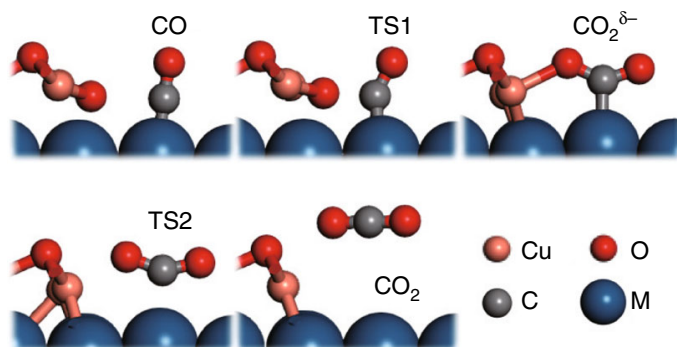

Fig. 6 DFT calculations about $\mathbf{C O}$ oxidation reaction on supported $\mathbf{C u}_{\mathbf{2}} \mathbf{O}$ NSs. a DFT-optimized structures of $\mathrm{Pt}(111), \mathrm{Au}(111), \mathrm{Ag}(111) \operatorname{supported}$ and freestanding $\mathrm{Cu}_{8} \mathrm{O}_{6}$ nanoribbons (denoted as $\mathrm{Cu}_{2} \mathrm{O} / \mathrm{M}\left(\mathrm{M}=\mathrm{Pt}, \mathrm{Au}, \mathrm{Ag}\right.$ ) and $\mathrm{Cu}_{2} \mathrm{O}-\mathrm{fs}$ ). $\mathbf{b}$ Potential energy diagram for the reaction between $\mathrm{CO}$ and $\mathrm{O}$ on the stabilized edge of $\mathrm{M}(111)$ supported $\mathrm{Cu}_{2} \mathrm{O}$ NSs. The value of barrier is labeled above the corresponding transition state (unit: eV). The energy of $\mathrm{CO}$ ( $\mathrm{g}$ ) is represented as the Gibbs free energy of $\mathrm{CO}$ under UHV conditions $\left(1 \times 10^{-7} \mathrm{mbar}\right)$ while the black dashed bar at $0 \mathrm{eV}$ marks the DFT-calculated energy of $\mathrm{CO}$ without corrections. The red and cyan dashed bars mark the adsorption energy of $\mathrm{CO}$ on the top site of $\mathrm{Au}(111)$ and $\mathrm{Ag}(111)$ surface near the edge of $\mathrm{Cu}_{2} \mathrm{O}$ NSs. c The formation energy of $\mathrm{O}$ vacancy for two kinds of $\mathrm{O}$ atoms, marked by red and blue dashed circles, at the edges of $\mathrm{Cu}_{2} \mathrm{O} / \mathrm{M}$ and $\mathrm{Cu}_{2} \mathrm{O}-\mathrm{fs}$. d The optimized structures for reaction intermediates and transition states (adsorbed $\mathrm{CO}$, transition state 1 ( $\mathrm{TS} 1$ ), $\mathrm{CO}_{2}$ adsorbed with bending configuration, transition state 2 (TS2) and $\mathrm{CO}_{2}$ adsorbed with straight configuration) in $\mathbf{b}$.

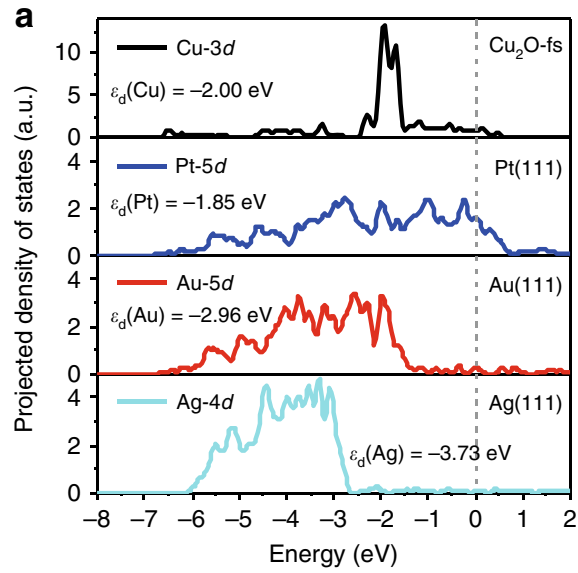

b

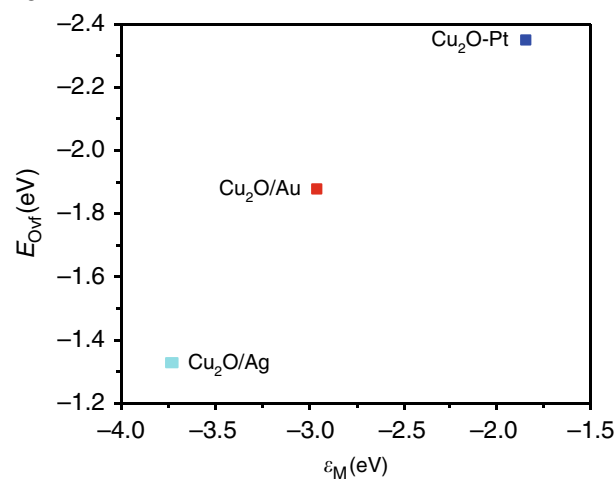

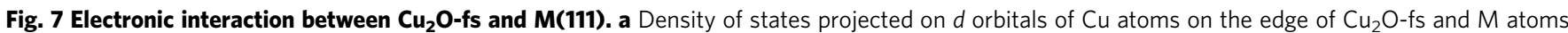
from the surface layer of $\mathrm{M}(111)(\mathrm{M}=\mathrm{Pt}, \mathrm{Au}, \mathrm{Ag})$ and their corresponding $d$ band centers. The grey dashed line marks the Fermi level. $\mathbf{b} E_{\mathrm{Ovf}}$ for $\mathrm{O}$ atoms at the edge of $\mathrm{Cu}_{2} \mathrm{O} / \mathrm{M}$ as a function of $d$ band center of $\mathrm{M}(111)$.

exhibit a substrate-dependent thermal stability. $\mathrm{Cu}_{2} \mathrm{O}$ NSs on $\mathrm{Pt}$ (111) showed a surprisingly low stability, with an onset decomposition temperature even lower than the desorption temperature of oxygen atoms on $\mathrm{Pt}(111)$. In contrast, $\mathrm{Cu}_{2} \mathrm{O}$
NSs on $\mathrm{Ag}(111)$ and $\mathrm{Au}(111)$ remained stable in UHV even after the annealing at up to $700 \mathrm{~K}$.

As we compared the reactivities of $\mathrm{Cu}_{2} \mathrm{O}$ NSs on $\mathrm{M}(111)$ for $\mathrm{CO}$ oxidation, we found all surfaces could react with $\mathrm{CO}$ at room 
temperature. But, the reduction of $\mathrm{Cu}_{2} \mathrm{O}$ on $\mathrm{Pt}(111)$ needs only a $\mathrm{CO}$ pressure at $5 \times 10^{-8}$ mbar, whereas the reduction of $\mathrm{Cu}_{2} \mathrm{O}$ on $\mathrm{Au}(111)$ requires a $\mathrm{CO}$ pressure at $0.5 \mathrm{mbar}$, and even much higher on $\mathrm{Ag}(111)$. Vice versa, the regeneration of $\mathrm{Cu}_{2} \mathrm{O} \mathrm{NSs}$ needs only $5 \times 10^{-8} \mathrm{mbar}_{2}$ on $\mathrm{Pt}(111)$, while the regeneration of $\mathrm{Cu}_{2} \mathrm{O}$ NSs requires NAP conditions on $\mathrm{Au}(111)\left(\sim 1 \mathrm{mbar}_{2}\right)$ and $\mathrm{Ag}(111)\left(\sim 0.2 \mathrm{mbar}_{2}\right)$. Further catalytic tests on powder samples corroborated that the interface with $\mathrm{Cu}_{2} \mathrm{O}$ NSs could annihilate the $\mathrm{CO}$-poisoning problem and enable low temperature $\mathrm{CO}$ oxidation on $\mathrm{Pt}$ group metals. The reactivity of supported $\mathrm{Cu}_{2} \mathrm{O}$ NSs is found determined and much enhanced by OMI, when compared with $\mathrm{Cu}_{2} \mathrm{O}$-fs. The analysis of reaction mechanism and OMI showed that OMI facilitates CO oxidation by enhancing the activity of interfacial oxygen atoms and stabilizing oxygen vacancies in $\mathrm{Cu}_{2} \mathrm{O}$ NSs. The stronger the $\mathrm{OMI}$, the lower the barrier for $\mathrm{CO}$ oxidation catalyzed by supported $\mathrm{Cu}_{2} \mathrm{O}$ NSs. The role of OMI in dictating the activity and stability of supported $\mathrm{Cu}_{2} \mathrm{O}$ NSs could be described by the formation energy of interfacial oxygen vacancy. Further, $d$ band center could serve as a simple descriptor for OMI to correlate the electronic interaction between $\mathrm{Cu}^{+}$and metal substrates with the formation energy of oxygen vacancy and the reactivity of $\mathrm{Cu}_{2} \mathrm{O}$ / $\mathrm{M}$ interfaces for $\mathrm{CO}$ oxidation. Thus, our study provides insight for OMI and a strategy for the design of oxide NS catalysts for oxidation reactions.

\section{Methods}

Model catalyst synthesis and characterization. The experiments were carried out in two UHV systems. The first system consists of a CreaTec LT-STM with base pressure at $<4 \times 10^{-11}$ mbar and a preparation chamber equipped with XPS, and cleaning facilities. LT-STM measurements were conducted at $78 \mathrm{~K}$, using an electrochemically etched $\mathrm{W}$ tip. The second system consists of a SPECS NAP-STM with base pressure $<2 \times 10^{-10}$ mbar and a preparation chamber equipped with cleaning facilities. NAP-STM measurements were conducted at $300 \mathrm{~K}$ using a Pt-Ir tip. $\mathrm{Pt}(111), \mathrm{Au}(111)$, and $\mathrm{Ag}(111)$ single crystals (Mateck) were cleaned by cycles of $\mathrm{Ar}^{+}$sputtering at $1.2 \mathrm{kV}$ and annealing to $800 \mathrm{~K}$ for $\mathrm{Au}(111)$ and $\mathrm{Ag}(111)$ or $1000 \mathrm{~K}$ for $\mathrm{Pt}(111)$ until no impurities were obvious on the surface from STM.

Well-ordered $\mathrm{Cu}_{2} \mathrm{O}$ NSs of ML thickness could be synthesized on metal single crystals by evaporating $\mathrm{Cu}$ in $1 \times 10^{-7} \mathrm{mbar}_{2}$ at cryogenic temperatures, which were followed by the annealing in $\mathrm{O}_{2}$ at $\sim 500 \mathrm{~K}$. To obtain well-ordered structure, $\mathrm{Cu}_{2} \mathrm{O} / \mathrm{Au}(111)$ and $\mathrm{Cu}_{2} \mathrm{O} / \mathrm{Ag}(111)$ could be annealed in UHV condition above 500 $\mathrm{K}$. On $\mathrm{Au}(111), \mathrm{Cu}_{2} \mathrm{O}$ NSs could be prepared by depositing $\mathrm{Cu}$ in $\sim 3 \times 10^{-7} \mathrm{mbar}$ $\mathrm{NO}_{2}$ at $300 \mathrm{~K}$, which were followed by the annealing in $\mathrm{NO}_{2}$ at $400 \mathrm{~K} . \mathrm{Cu}_{2} \mathrm{O} / \mathrm{Ag}$ (111) could also be prepared by oxidation of $\mathrm{Cu} / \mathrm{Ag}(111)$ by near ambient pressure of $\mathrm{O}_{2}$ at $300 \mathrm{~K}$. Then to remove the surface $\mathrm{Ag}-\mathrm{O}$ species, $\mathrm{Cu}_{2} \mathrm{O} / \mathrm{Ag}(111)$ was annealed at $\sim 450 \mathrm{~K}$. For all experiments, $\mathrm{O}_{2}$ and $\mathrm{CO}$ were purified by liquid nitrogen for over $1 \mathrm{~h}$ to remove impurities before being introduced into the chambers. Different modes of ES-STM images were acquired using W tip and controlling the indentation of $\mathrm{W}$ tip into the $\mathrm{Cu}_{2} \mathrm{O}$ surface to obtain a $\mathrm{CuO}_{\mathrm{x}}$ terminated tip 29,49 . All STM images were processed with SPIP software (Image Metrology). XPS characterization of $\mathrm{Cu}_{2} \mathrm{O} / \mathrm{Pt}(111)$ was conducted with $\mathrm{Mg}$-ka energy source $(h v=1253.6 \mathrm{eV})$. The binding energies were calibrated with that of Pt $4 f_{7 / 2}$ signal located at $71.0 \mathrm{eV}$.

Powder catalysts preparation and catalytic tests. $\mathrm{PtCu} / \mathrm{CB}$ catalyst was prepared by co-impregnation method. First, $100 \mathrm{mg} \mathrm{CB}$ (Vulcan XC-72) were dispersed into $5 \mathrm{~mL} \mathrm{H} \mathrm{H}_{2} \mathrm{O}$ by ultrasonic treatment for $0.5 \mathrm{~h}$. Next the aqueous solutions of $\mathrm{H}_{2} \mathrm{PtCl}_{6}$ and $\mathrm{Cu}\left(\mathrm{NO}_{3}\right)_{2}$ were successively added. The nominal loading of Pt was $4 \mathrm{wt} \%$, and the molar ratio of $\mathrm{Cu}$ to $\mathrm{Pt}$ was 1:4. Then, excess water was evaporated at room temperature under continuous agitation $(500 \mathrm{rpm})$. Finally, the solid was dried at $333 \mathrm{~K}$ in an oven for $12 \mathrm{~h}$ to obtain the catalyst for use. The preparation procedures for $\mathrm{AuCu} / \mathrm{CB}$ and $\mathrm{AgCu} / \mathrm{CB}$ catalysts were exactly the same as that for $\mathrm{PtCu} / \mathrm{CB}$ by only replacing the precursor into $\mathrm{HAuCl}_{4}$ or $\mathrm{AgNO}_{3}$ respectively. $\mathrm{Pt} / \mathrm{CB}, \mathrm{Au} / \mathrm{CB}$, and $\mathrm{Ag} / \mathrm{CB}$ were prepared in similar manner but without addition of $\mathrm{Cu}\left(\mathrm{NO}_{3}\right)_{2}$. The $\mathrm{Cu}_{2} \mathrm{O}$ powder ( $99 \%$ purity) was bought from Energy Chemical.

$\mathrm{CO}$ oxidation was carried out in a fixed-bed reactor. The reactant gas consisted of $1 \% \mathrm{CO}, 20 \% \mathrm{O}_{2}$, and $79 \% \mathrm{He}$ (Messer). The reactant gas was flowed at $20 \mathrm{~mL} \mathrm{~min}^{-1}$ through $20 \mathrm{mg}$ catalyst to achieve a space velocity of $60,000 \mathrm{~mL} \mathrm{~g}^{-1} \mathrm{~h}^{-1}$. The tail gas was analyzed online by gas chromatography equipped with methane converter in front of flame ionization detector. Before reactions, all catalysts were reduced in highpurity $\mathrm{H}_{2}$ flow at $473 \mathrm{~K}$ for $2 \mathrm{~h}$. After cooling down in high-purity Ar flow, samples were kept in reactant gas for $1 \mathrm{~h}$ at $298 \mathrm{~K}$, then temperature-dependent $\mathrm{CO}$ oxidation was performed from room temperature to $573-673 \mathrm{~K}$ at a rate of $1 \mathrm{~K} \mathrm{~min}^{-1}$.
XPS analysis of powder catalysts were performed in ThermoFischer ESCALAB 250Xi photoelectron spectrometer using monochromated X-ray irradiation $\mathrm{Al}-\mathrm{Ka}$ $(h v=1486.7 \mathrm{eV})$ and $180^{\circ}$ double focusing hemispherical analyzer with a six channel detector. The binding energies of the photoemission spectra were calibrated to $\mathrm{C} 1 s$ peak at $284.4 \mathrm{eV}$. The XPS chamber is attached with a highpressure reactor for catalytic studies. Samples were reduced in pure hydrogen (1 bar) to $473 \mathrm{~K}$ for $1 \mathrm{~h}$ and then cooled to $300 \mathrm{~K}$ in $\mathrm{H}_{2}$. $\mathrm{CO}$ oxidation reaction was then performed in the mixture gas ( 1 bar, $1 \% \mathrm{CO}$ and $20 \% \mathrm{O}_{2}$ with He balance) to $400 \mathrm{~K}$ for $\mathrm{PtCu} / \mathrm{CB}$ or $500 \mathrm{~K}$ for $\mathrm{AuCu} / \mathrm{CB}$ and $\mathrm{AgCu} / \mathrm{CB}$. After reaction, the sample was cooled to room temperature in reactant gas. XPS measurements were performed after evacuating the reactor cell and transferring the samples in UHV into the analyzer chamber without air exposure.

Computational method. Theoretical calculations were carried out based on density functional theory (DFT) framework by using Vienna ab initio simulation packages $(\text { VASP })^{50}$ with the projector augmented wave (PAW $)^{51}$ scheme and the plane-wave basis set with the cutoff energy of $400 \mathrm{eV}$ were adopted ${ }^{52}$. The generalized gradient approximation (GGA) functional developed by Perdew-Burke-Ernzerhof (PBE) ${ }^{53}$ for the exchange-correlation term was used. The method of Methfessel-Paxton was employed to define the partial occupancies of metal-supported or freestanding $\mathrm{Cu}_{8} \mathrm{O}_{6}$ (each supercell includes $8 \mathrm{Cu}$ and $6 \mathrm{O}$ ) ribbon. Climbing image nudged elastic band (NEB) method ${ }^{54,55}$ was used for searching of transition states. All the models were well converged until the forces decreased to less than $0.05 \mathrm{eV}^{-1}$. Models of $\mathrm{Cu}_{8} \mathrm{O}_{6}$ nanoribbons on $\mathrm{Pt}(111), \mathrm{Au}(111)$, and $\mathrm{Ag}(111)$ were adopted. For each model, a 4-layer $2 \times 4 \sqrt{3}$ supercell of $\mathrm{M}(111)(\mathrm{M}=\mathrm{Pt}, \mathrm{Au}, \mathrm{Ag})$ surface was used as substrate Gamma-centered K-mesh of $4 \times 1 \times 1$ was employed for structure optimization or transition-state searching. 4-layer $4 \times 4 \mathrm{M}(111)(\mathrm{M}=\mathrm{Pt}, \mathrm{Au}, \mathrm{Ag})$ surface with Gamma-centered K-mesh of $4 \times 4 \times 1$ were adopted as reference of pure metal for CO adsorption calculations. For all models, the vacuum was set to be about $12 \AA$. During structure optimization, the bottom layer of substrate was constrained while the rest parts were fully relaxed. Freestanding $\mathrm{Cu}_{8} \mathrm{O}_{6}$ nanoribbon was fully relaxed at the fixed lattice in bulk value $(6.105 \AA)$ with the Gamma-centered K-mesh $4 \times 1 \times 1$.

The $d$ band center $\left(\varepsilon_{\mathrm{d}}\right)$ was calculated through the formula ${ }^{56}$ below:

$$
\varepsilon_{\mathrm{d}}=\frac{\int_{-\infty}^{\infty} n_{\mathrm{d}}(\varepsilon) \varepsilon \mathrm{d} \varepsilon}{\int_{-\infty}^{\infty} n_{\mathrm{d}}(\varepsilon) \mathrm{d} \varepsilon},
$$

where $\varepsilon$ is energy and $n_{\mathrm{d}}(\varepsilon)$ is the density of states of electrons. Integral interval is from negative infinity to positive infinity.

Surface rumpling was defined as $\Delta h$, which is calculated through the formula:

$$
\Delta h=\frac{\sum_{i=1}^{n}\left|h_{\mathrm{Oi}}-\overline{h_{\mathrm{Cu}}}\right|}{n},
$$

where $h_{\mathrm{Oi}}$ is the height of the ith $\mathrm{O}, \overline{h_{\mathrm{Cu}}}$ is the average height of $\mathrm{Cu}, n$ is the number of $\mathrm{O}$ in $\mathrm{Cu}_{8} \mathrm{O}_{6}$ nanoribbon.

Adhesion energy $E_{\text {adh }}$ was calculated through the formula:

$$
E_{\mathrm{adh}}=E_{\mathrm{tot}}-E_{\mathrm{oxi}}-E_{\mathrm{M}},
$$

where $E_{\text {tot }}$ is DFT-calculated total energy for $\mathrm{M}(111)$ supported $\mathrm{Cu}_{8} \mathrm{O}_{6}$ nanoribbon; $E_{\text {oxi }}$ and $E_{\mathrm{M}}$ are energy for freestanding $\mathrm{Cu}_{8} \mathrm{O}_{6}$ nanoribbon and $\mathrm{M}(111)$, respectively.

Oxygen vacancy formation energy $\left(E_{\text {Ovf }}\right)$ is the energy needed to remove one oxygen from $\mathrm{Cu}_{8} \mathrm{O}_{6}$ nanoribbons, referencing to $\mathrm{CO}$ and $\mathrm{CO}_{2}$ in gas phase, which is calculated through the formula below:

$$
E_{\mathrm{Ovf}}=E_{\mathrm{Ovac}}+E_{\mathrm{CO}_{2}}-E_{\mathrm{CO}}-E_{\mathrm{per}},
$$

where $E_{\mathrm{Ovac}}$ and $E_{\mathrm{per}}$ are DFT-calculated total energy for structures with one oxygen vacancy and without that, respectively; $E_{\mathrm{CO}_{2}}$ and $E_{\mathrm{CO}}$ are energy for $\mathrm{CO}_{2}$ and $\mathrm{CO}$ in gas phase.

The Gibbs free energy of $\mathrm{CO}\left(G_{\mathrm{CO}}\right)$ in gas phase is calculated through the formula below:

$$
G_{\mathrm{CO}}=E_{\text {elec }}+\mathrm{ZPE}+\int C_{p} \mathrm{~d} T-\mathrm{TS}+k T \ln \mathrm{P}_{\mathrm{CO}} / p_{0},
$$

where $E_{\text {elec }}$ is the electronic energy calculated via VASP; ZPE is the zero-point energy, $\int C_{p} \mathrm{~d} T$ is the variety of isobaric heat capacity as the temperature changes, $S$ is entropy and $T$ is $298 \mathrm{~K} . p_{\mathrm{CO}}$ and $p_{0}$ is the pressure of $\mathrm{CO}$ and the standard atmosphere (1000 mbar) respectively; $k$ is the Boltzmann constant. The results of $\mathrm{ZPE}, \int C_{p} \mathrm{~d} T, S$ is given by the ASE (atomic simulation environment) $\operatorname{code}^{57}$.

\section{Data availability}

All data supporting this work are available from the corresponding author upon reasonable request.

Received: 20 July 2019; Accepted: 2 April 2020;

Published online: 08 May 2020 


\section{References}

1. Yu, W., Porosoff, M. D. \& Chen, J. G. Review of Pt-based bimetallic catalysis: from model surfaces to supported catalysts. Chem. Rev. 112, 5780-5817 (2012).

2. Thayer, A. M. Catalyst suppliers face changing industry. Chem. Eng. News 70, 27-49 (1992).

3. Guo, Z. et al. Recent advances in heterogeneous selective oxidation catalysis for sustainable chemistry. Chem. Soc. Rev. 43, 3480-3524 (2014).

4. Armor, J. N. Environmental catalysis. Appl. Catal. B 1, 221-256 (1992).

5. Grimaud, A., Hong, W. T., Shao-Horn, Y. \& arascon, J. M. Anionic redox processes for electrochemical devices. Nat. Mater. 15, 121-126 (2016).

6. Wu, C. H. et al. Bimetallic synergy in cobalt-palladium nanocatalysts for $\mathrm{CO}$ oxidation. Nat. Catal. 2, 78-85 (2019).

7. Zavabeti, A. et al. A liquid metal reaction environment for the roomtemperature synthesis of atomically thin metal oxides. Science 358, 332-335 (2017).

8. Tauster, S. J., Fung, S. C. \& Garten, R. L. Strong metal-support interactions. Group 8 noble metals supported on titanium dioxide. J. Am. Chem. Soc. 100, 170-175 (1978).

9. Fester, J. et al. Edge reactivity and water-assisted dissociation on cobalt oxide nanoislands. Nat. Commun. 8, 14169 (2017).

10. Rodriguez, J. A. et al. Inverse oxide/metal catalysts in fundamental studies and practical applications: a perspective of recent developments. J. Phys. Chem. Lett. 7, 2627-2639 (2016).

11. Senanayake, S. D., Stacchiola, D. \& Rodriguez, J. A. Unique properties of ceria nanoparticles supported on metals: novel inverse ceria/copper catalysts for $\mathrm{CO}$ oxidation and the water-gas shift reaction. Acc. Chem. Res. 46, 1702-1711 (2013).

12. $\mathrm{Fu}, \mathrm{Q}$. et al. Interface-confined ferrous centers for catalytic oxidation. Science 328, 1141-1144 (2010).

13. Fester, J. et al. The structure of the cobalt oxide/Au catalyst interface in electrochemical water splitting. Angew. Chem. Int. Ed. 57, 11893-11897 (2018).

14. Baber, A. E. et al. In situ imaging of $\mathrm{Cu}_{2} \mathrm{O}$ under reducing conditions: formation of metallic fronts by mass transfer. J. Am. Chem. Soc. 135 16781-16784 (2013).

15. Schmieder, P., Denysenko, D., Grzywa, M., Magdysyuk, O. \& Volkmer, D. A structurally flexible triazolate-based metal-organic framework featuring coordinatively unsaturated copper(I) sites. Dalton Trans. 45, 13853-13862 (2016).

16. Oezaslan, M., Heggen, M. \& Strasser, P. Size-dependent morphology of dealloyed bimetallic catalysts: linking the nano to the macro scale. J. Am. Chem. Soc. 134, 514-524 (2011).

17. Jiang, K. et al. Ordered PdCu-based nanoparticles as bifunctional oxygenreduction and ethanol-oxidation electrocatalysts. Angew. Chem. Int. Ed. 55, 9030-9035 (2016).

18. Guo, S. et al. Nanocatalyst superior to Pt for oxygen reduction reactions: the case of core/shell $\mathrm{Ag}(\mathrm{Au}) / \mathrm{CuPd}$ nanoparticles. J. Am. Chem. Soc. 136, 15026-15033 (2014).

19. Strasser, P. et al. Lattice-strain control of the activity in dealloyed core-shell fuel cell catalysts. Nat. Chem. 2, 454-460 (2010).

20. Koh, S. \& Strasser, P. Electrocatalysis on bimetallic surfaces: modifying catalytic reactivity for oxygen reduction by voltammetric surface dealloying. J. Am. Chem. Soc. 129, 12624-12625 (2007).

21. Della Pina, C., Falletta, E. \& Rossi, M. Update on selective oxidation using gold. Chem. Soc. Rev. 41, 350-369 (2012).

22. Zhao, G. et al. Metal/oxide interfacial effects on the selective oxidation of primary alcohols. Nat. Commun. 8, 14039 (2017).

23. Zheng, X. et al. Epoxidation of propylene by molecular oxygen over unsupported AgCux bimetallic catalyst. Rare Met. 34, 477-490 (2015).

24. Huang, J. et al. The effect of the support on the surface composition of $\mathrm{PtCu}$ alloy nanocatalysts: In situ XPS and HS-LEIS studies. Chin. J. Catal. 38, 1229-1236 (2017).

25. Friebel, D. et al. Structure, redox chemistry, and interfacial alloy formation in monolayer and multilayer $\mathrm{Cu} / \mathrm{Au}(111)$ model catalysts for $\mathrm{CO}_{2}$ electroreduction. J. Phys. Chem. C 118, 7954-7961 (2014).

26. Zhao, L., Kong, L., Liu, C., Wang, Y. \& Dai, L. AgCu/SiC-powder: a highly stable and active catalyst for gas-phase selective oxidation of alcohols. Catal. Commun. 98, 1-4 (2017).

27. Liu, Q. et al. Tuning the structures of two-dimensional cuprous oxide confined on Au(111). Nano Res. 11, 5957-5967 (2018).

28. Liu, Y. et al. Enhanced oxidation resistance of active nanostructures via dynamic size effect. Nat. Commun. 8, 14459 (2017).

29. Monig, H. et al. Understanding scanning tunneling microscopy contrast mechanisms on metal oxides: a case study. ACS Nano 7, 10233-10244 (2013).

30. Yang, F. et al. Identification of 5-7 defects in a copper oxide surface. J. Am Chem. Soc. 133, 11474-11477 (2011).
31. Fester, J. et al. Comparative analysis of cobalt oxide nanoisland stability and edge structures on three related noble metal surfaces: $\mathrm{Au}(111), \mathrm{Pt}(111)$ and $\mathrm{Ag}$ (111). Top. Catal. 60, 503-512 (2016).

32. Parker, D. H., Bartram, M. E. \& Koel, B. E. Study of high coverages of atomic oxygen on the Pt (111) surface. Surf. Sci. 217, 489-510 (1989)

33. Hammer, B., Morikawa, Y. \& Norskov, J. K. CO chemisorption at metal surfaces and overlayers. Phys. Rev. Lett. 76, 2141-2144 (1996).

34. Predel B. Cu-Pt (Copper-Platinum). (Springer, Berlin Heidelberg, 1994).

35. Kinne, M. et al. Kinetics of the CO oxidation reaction on $\mathrm{Pt}(111)$ studied by in situ high-resolution x-ray photoelectron spectroscopy. J. Chem. Phys. 120, 7113--7122 (2004)

36. Cox, D. F. \& Schulz, K. H. Interaction of $\mathrm{CO}$ with $\mathrm{Cu}+$ cations: $\mathrm{CO}$ adsorption on $\mathrm{Cu} 2 \mathrm{O}(100)$. Surf. Sci. 249, 138-148 (1991).

37. Su, H.-Y., Yang, M.-M., Bao, X.-H. \& Li, W.-X. The effect of water on the CO oxidation on $\mathrm{Ag}(111)$ and $\mathrm{Au}(111)$ surfaces: a first-principle study. J. Phys. Chem. C 112, 17303-17310 (2008).

38. Andryushechkin, B. V., Shevlyuga, V. M., Pavlova, T. V., Zhidomirov, G. M. \& Eltsov, K. N. Adsorption of $\mathrm{O}_{2}$ on $\mathrm{Ag}(111)$ : evidence of local oxide formation. Phys. Rev. Lett. 117, 056101 (2016).

39. Hansen, W., Bertolo, M. \& Jacobi, K. Physisorption of CO on Ag(111): investigation of the monolayer and the multilayer through HREELS, ARUPS, and TDS. Surf. Sci. 253, 1-12 (1991).

40. Montemore, M. M., van Spronsen, M. A., Madix, R. J. \& Friend, C. M. O activation by metal surfaces: implications for bonding and reactivity on heterogeneous catalysts. Chem. Rev. 118, 2816-2862 (2018).

41. Liu, X. et al. Structural changes of $\mathrm{Au}-\mathrm{Cu}$ bimetallic catalysts in $\mathrm{CO}$ oxidation: in situ XRD, EPR, XANES, and FT-IR characterizations. J. Catal. 278, 288-296 (2011)

42. Kim, J. et al. Adsorbate-driven reactive interfacial Pt-NiO1-x nanostructure formation on the Pt3Ni(111) alloy surface. Sci. Adv. 4, eaat3151 (2018).

43. Poulston, S., Parlett, P. M., Stone, P. \& Bowker, M. Surface oxidation and reduction of $\mathrm{CuO}$ and $\mathrm{Cu}_{2} \mathrm{O}$ studied using XPS and XAES. Surf. Interface Anal. 24, 811-820 (1996).

44. Hopster, H. \& Ibach, H. Adsorption of CO on Pt(111) and Pt $6(111) \times(111)$ studied by high resolution electron energy loss spectroscopy and thermal desorption spectroscopy. Surf. Sci. 77, 109-117 (1978).

45. Schnadt, J. et al. Experimental and theoretical study of oxygen adsorption structures on $\operatorname{Ag}(111)$. Phys. Rev. B 80, 075424 (2009).

46. Green, I. X., Tang, W. J., Neurock, M. \& Yates, J. T. Spectroscopic observation of dual catalytic sites during oxidation of $\mathrm{CO}$ on a $\mathrm{Au} / \mathrm{TiO}_{2}$ catalyst. Science 333, 736-739 (2011).

47. Hammer B. \& Nørskov J. K. Theoretical Surface Science and CatalysisCalculations and Concepts. (Academic Press, 2000).

48. Chen, $\mathrm{H}$. et al. $\mathrm{CO}$ and $\mathrm{H}_{2}$ activation over $\mathrm{g}-\mathrm{ZnO}$ layers and $\mathrm{w}-\mathrm{ZnO}(0001)$. ACS Catal. 9, 1373-1382 (2019).

49. Mönig, H. et al. Quantitative assessment of intermolecular interactions by atomic force microscopy imaging using copper oxide tips. Nat. Nanotechnol. 13, 371-375 (2018).

50. Kresse, G. \& Hafner, J. Ab initio molecular dynamics for liquid metals. Phys Rev. B 47, 558-561 (1993).

51. Hobbs, D., Kresse, G. \& Hafner, J. Fully unconstrained noncollinear magnetism within the projector augmented-wave method. Phys. Rev. B 62 11556-11570 (2000).

52. Kresse, G. \& Furthmuller, J. Efficient iterative schemes for ab initio total-energy calculations using a plane-wave basis set. Phys. Rev. B 54, 11169-11186 (1996).

53. Perdew, J. P., Burke, K. \& Ernzerhof, M. Generalized gradient approximation made simple. Phys. Rev. Lett. 77, 3865-3868 (1996).

54. Henkelman, G. \& Jónsson, H. Improved tangent estimate in the nudged elastic band method for finding minimum energy paths and saddle points. J. Chem. Phys. 113, 9978-9985 (2000).

55. Henkelman, G., Uberuaga, B. P. \& Jónsson, H. A climbing image nudged elastic band method for finding saddle points and minimum energy paths. $J$. Chem. Phys. 113, 9901-9904 (2000).

56. Nørskov, J. K. N., Studt, F., Abild-Pedersen, F. \& Bligaard, T. Fundamental Concepts in Heterogeneous Catalysis. (Wiley, 2014).

57. Hjorth Larsen, A. et al. The atomic simulation environment-a Python library for working with atoms. J. Phys. Condens. Matter 29, 273002 (2017).

\section{Acknowledgements}

This work was financially supported by Ministry of Science and Technology of China (2017YFB0602205, 2016YFA0202803), National Natural Science Foundation of China (21972144, 91545204, 11227902), and Strategic Priority Research Program of the Chinese Academy of Sciences (XDB17020200). The authors thank Evgeny Vovk for helping with XPS measurements of powder catalysts and the support from Analytical Instrumentation Center (contract no. SPST-AIC10112914), SPST, ShanghaiTech University. Dedicated to the 70th anniversary of Dalian Institute of Chemical Physics, CAS. 


\section{Author contributions}

F.Y. and X.B. designed and supervised the project. W.H., Q.L., Ya.L., and Yu.L. carried out the STM and XPS experiments. Z.Z. and B.Y. carried out the DFT calculations. Y.W., Y.T., and D.D. carried out preparation and catalytic tests of powder catalysts. B.W., X.Z., Y.Y., and Z.L. carried out the TEM and XPS analysis of powder catalysts. F.Y., W.H., and Z.Z. prepared this manuscript.

\section{Competing interests}

The authors declare no competing interests.

\section{Additional information}

Supplementary information is available for this paper at https://doi.org/10.1038/s41467020-15965-8.

Correspondence and requests for materials should be addressed to F.Y.

Peer review information Nature Communications thanks the anonymous reviewer(s) for their contribution to the peer review of this work.
Reprints and permission information is available at http://www.nature.com/reprints

Publisher's note Springer Nature remains neutral with regard to jurisdictional claims in published maps and institutional affiliations.

\section{(c) (i)}

Open Access This article is licensed under a Creative Commons Attribution 4.0 International License, which permits use, sharing, adaptation, distribution and reproduction in any medium or format, as long as you give appropriate credit to the original author(s) and the source, provide a link to the Creative Commons license, and indicate if changes were made. The images or other third party material in this article are included in the article's Creative Commons license, unless indicated otherwise in a credit line to the material. If material is not included in the article's Creative Commons license and your intended use is not permitted by statutory regulation or exceeds the permitted use, you will need to obtain permission directly from the copyright holder. To view a copy of this license, visit http://creativecommons.org/licenses/by/4.0/.

(C) The Author(s) 2020 